\title{
ASIA-PACIFIC REGIONAL INTEGRATION INDEX: CONSTRUCTION, INTERPRETATION, AND COMPARISON
}

Hyeon-Seung Huh and Cyn-Young Park

NO. 511

April 2017
ADB ECONOMICS WORKING PAPER SERIES 
ADB Economics Working Paper Series

\section{Asia-Pacific Regional Integration Index: Construction, Interpretation, and Comparison}

Hyeon-Seung Huh and Cyn-Young Park

No. 511 | April 2017
Hyeon-Seung Huh (hshuh@yonsei.ac.kr) is a professor at Yonsei University, Seoul, Republic of Korea. Cyn-Young Park (cypark@adb.org) is director of the Regional Cooperation and Integration Division in the Economic Research and Regional Cooperation Department of the Asian Development Bank.

The authors thank Hyun-Hoon Lee for very helpful suggestions, and Racquel Claveria, Pilar Dayag, Seong-Eun Kang, Paul Mariano, and Mara Claire Tayag for their devoted and timeless efforts in collecting and compiling data. 
(C) 2017 Asian Development Bank

6 ADB Avenue, Mandaluyong City, 1550 Metro Manila, Philippines

Tel +632632 4444; Fax +6326362444

www.adb.org

Some rights reserved. Published in 2017.

ISSN 2313-6537 (Print), 2313-6545 (e-ISSN)

Publication Stock No. WPS178772-2

DOI: http://dx.doi.org/10.22617/WPS178772-2

The views expressed in this publication are those of the authors and do not necessarily reflect the views and policies of the Asian Development Bank (ADB) or its Board of Governors or the governments they represent.

ADB does not guarantee the accuracy of the data included in this publication and accepts no responsibility for any consequence of their use. The mention of specific companies or products of manufacturers does not imply that they are endorsed or recommended by ADB in preference to others of a similar nature that are not mentioned.

By making any designation of or reference to a particular territory or geographic area, or by using the term "country" in this document, $A D B$ does not intend to make any judgments as to the legal or other status of any territory or area.

This work is available under the Creative Commons Attribution 3.0 IGO license (CC BY 3.0 IGO)

https://creativecommons.org/licenses/by/3.0/igo/. By using the content of this publication, you agree to be bound by the terms of this license. For attribution, translations, adaptations, and permissions, please read the provisions and terms of use at https://www.adb.org/terms-use\#openaccess

This CC license does not apply to non-ADB copyright materials in this publication. If the material is attributed to another source, please contact the copyright owner or publisher of that source for permission to reproduce it. $\mathrm{ADB}$ cannot be held liable for any claims that arise as a result of your use of the material.

Please contact pubsmarketing@adb.org if you have questions or comments with respect to content, or if you wish to obtain copyright permission for your intended use that does not fall within these terms, or for permission to use the ADB logo.

Notes:

1. In this publication, "\$" refers to US dollars.

2. Corrigenda to ADB publications may be found at http://www.adb.org/publications/corrigenda 


\section{CONTENTS}

TABLES AND FIGURES

ABSTRACT

$\begin{array}{ll}\text { I. INTRODUCTION } & 1\end{array}$

II. STRUCTURE OF APRII AND DATA TREATMENT 3

A. Index Composition and Data Descriptions 3

B. Treatment of Missing Data 5

C. Countries Covered 5

D. Year Coverage $\quad 5$

E. Normalization $\quad 6$

III. AGGREGATION SCHEME

$\begin{array}{ll}\text { IV. } & \text { EMPIRICALRESULTS }\end{array}$

V. COMPARISONS TO OTHER REGIONS

$\begin{array}{lll}\text { VI. CONCLUSION } & 21\end{array}$

$\begin{array}{ll}\text { APPENDIXES } & 25\end{array}$

$\begin{array}{lr}\text { REFERENCES } & 29\end{array}$ 


\section{TABLES AND FIGURES}

\section{TABLES}

$1 \quad$ Asia-Pacific Regional Integration Index: Dimensions and Indicators 4

2 Principal Component Analysis and Weights for Aggregation 9

3 Weight Summary for Asia-Pacific Regional Integration Index 11

4 Principal Component Analysis and Weights for Aggregation: EU, Latin America, and Africa

$5 \quad$ World Rankings of the Overall Regional Integration Index

\section{FIGURES}

$1 \quad$ Asia Regional Integration Index: Overall

2 Asia-Pacific Regional Integration Index: Dimensions

3a Overall Integration Index by Subregion

15

3b Subregional Integration Indexes by Dimension $\quad 15$

3c The Summary of APRII by Subregions 16

$4 \quad$ Regional Integration Indexes with the Worldwide Normalization 20

5 The Summary of Regional Integration Indexes with the Worldwide Normalization 


\begin{abstract}
We develop an index to measure the degree of regional integration in Asia and the Pacific (48 economies in six subregions). The index comprises 26 indicators in six dimensions of regional integration, i.e., trade and investment, money and finance, regional value chains, infrastructure and connectivity, free movement of people, and institutional and social integration. We use principal component analysis to apportion a weight to each dimension and indicator to construct composite indexes. The resulting indexes help assess the state of regional integration on diverse socioeconomic dimensions, evaluate progress against goals, identify strengths and weaknesses, and track progress. Cross-country, cross-regional comparisons also allow policy makers to prioritize areas for further efforts.
\end{abstract}

Keywords: Asia, composite index, regional integration

JEL codes: $\mathrm{F} 10, \mathrm{~F} 30, \mathrm{O} 10, \mathrm{O} 50$ 


\section{INTRODUCTION}

Regional integration is a process in which a group of neighboring economies expand mutually beneficial economic activities and coordinate policies to pursue common economic and/or political goals. Integration can occur through promoting trade and investment, developing infrastructure, improving people's mobility, and strengthening the provision of regional public goods and the legal and institutional basis for policy cooperation.

Asia has progressed rapidly on regional economic integration over the past few decades, although there are significant variations across different subregions. Economic integration in East and Southeast Asia is most advanced, driven by growing trade and foreign direct investment (FDI) networks linked to global supply chains. Trade and FDI liberalization accelerated in the 1980s and 1990s around Asia, with many economies entering free trade agreements (FTAs). As of January 2017, 147 FTAs were in effect and another 151 under negotiation or proposed in 48 regional member economies of the Asian Development Bank. ' However, regional integration in Asia has been market led and bottom up, often lacking strong regional institutions and regional governance.

Following the 1997 financial crisis, Asian countries recognized the need to establish a regional mechanism to avert future crises, mitigate the risks of financial contagion, and enhance regional policy dialogue and cooperation to address potential policy spillovers. Several regional initiatives have been introduced to develop and strengthen regional institutions and accelerate regional cooperation and integration. For example, the Association of Southeast Asian Nations plus Three (ASEAN+3) countries (ASEAN, the People's Republic of China [PRC], Japan, and the Republic of Korea) implemented the Chiang Mai Initiative in 2000 (bilateral) and 2010 (multilateral) to advance financial and monetary cooperation. Momentum picked up as global trade talks stalled in the late 1990s and again amid weak global demand after the 2008-2009 global financial crisis, both prompting greater favor among Asian policy makers for deeper regional economic integration.

Bilateral and multilateral (or regional) trade agreements have proliferated in Asia over the past two decades (WTO 2011). In addition, the ASEAN Economic Community (AEC) was established as a cornerstone of economic integration in a regional market of $\$ 2.6$ trillion dollars and over 622 million people. The AEC aims for an integrated and cohesive regional economy that supports sustained growth and inclusive development by 2025 (under the AEC Blueprint 2025) (ASEAN 2015).

Deeper regional integration expands markets, helps maximize the efficiency of resource allocation, and boosts productivity and investment opportunities, all serving stronger economies. It may also produce important noneconomic benefits through greater security and political stability and sociocultural harmonization. To take advantage of these benefits, policy makers must install mechanisms to monitor and evaluate progress and judge it against set goals. Against this backdrop, the present study proposes a regional integration index for Asia and the Pacific (Asia-Pacific Regional Integration Index, i.e. APRII) that can assess the degree of integration on different socioeconomic dimensions across 48 economies and six subregions, compare strengths and weaknesses, and track progress.

The APRII comprises 26 indicators that measure various aspects of regional integration along six dimensions: trade and investment integration, money and finance integration, regional value chains, infrastructure and connectivity, free movement of people, and institutional and social integration. We

1 See the ADB Asia Regional Integration Center, FTA Database at https://aric.adb.org/fta 
apportion 26 indicators to capture the contributions of these six socioeconomic dimensions to overall regional integration. The construction of our index entails two steps: first, we weight-averaged indicators in each dimension to produce a composite dimensional index; second, we weight-averaged the derived dimensional indexes, yielding an overall index of regional integration.

In each step, the weights are determined based on principal component analysis (PCA). PCA is one of the most commonly used multivariate statistical methods for creating a composite index. In particular, it combines a set of variables to extract maximum information common across these individual indicators. According to Gwartney and Lawson (2001), this procedure is particularly appropriate when each component measures different aspects of a composite index. PCA is also recommended as a very useful tool among weighting schemes currently available, especially when each dimension has a small number of indicators (such as from 3 to 10) (OECD 2008).

APRII is not the first of its kind. Early in 2016, the African Union Commission, the African Development Bank, and the UN Economic Commission for Africa (2016a) collaborated to publish the first edition of the Africa Regional Integration Index. Declaring regional integration as a development priority for Africa, the index is designed to track member countries' progress toward shared regional integration goals. It is also intended to identify gaps and inform policy decisions on how best to meet aspirations and commitments for regional integration (Africa Research Bulletin 2015). Africa Regional Integration Index has five dimensions: trade integration, productive integration (regional value chain), infrastructure, free movement of people, and financial and macroeconomic integration. It apportions 16 indicators relevant to the nature and characteristics of these five dimensions. ${ }^{2}$

APRII shares motivations and spirit similar to the Africa Regional Integration Index and we adopt the same construction process. However, two important features distinguish APRII from the Africa Regional Integration Index. One is that APRII incorporates the role of cross-border investment flows and increasingly interconnected financial markets in promoting regional integration. For example, trade and investment integration looks at FDI flows, in line with trade and FDI linkages widely recognized in the economic literature, and their impact on regional integration. In particular, the establishment of local export platforms by multinational manufacturing firms largely drives FDI flow in Asia, reflecting the trade and FDI nexus (ADB 2016). Money and finance integration considers both quantity and price measures of market integration through cross-border equity and bond investment flows and equity return correlations, as well as convergence of cross-border interest rate spreads for monetary policy transmission. With financial deregulation and liberalization in recent decades, monetary and financial markets are increasingly interconnected regionally and globally, and integration in this area is expected to gain importance in overall economic integration. APRII also explicitly accounts for treaties related to investment and finance with foreign countries. None of these components is present in the Africa Regional Integration Index. ${ }^{3}$

Another feature of APRII is structural, that is, in the construction of the composite index; the Africa Regional Integration Index adopts an arithmetic average to construct dimensional and overall indexes whereby all components are weighted equally in the aggregation. This equal weighting works well if all indicators are uncorrelated and all dimensions have an equal number of indicators. If some indicators are highly correlated, however, combining these variables with equal weights will likely

2 For more details, see Methodology for Calculating the Africa Regional Integration Index and Africa Regional Integration Index Report 2016, both downloadable at http://www.integrate-africa.org

3 The financial and macroeconomic dimension in the Africa Regional Integration Index has two indicators: regional convertibility of national currencies and inflation rate differentials. 
induce double counting into a composite index. Also, when each dimension features a different number of indicators, equal weighting may imply a higher weight to the dimension that is represented by more indicators. This could result in an unbalanced structure in the composite index (OECD 2008). Weights based on PCA are not subject to these issues, because it utilizes the correlation structure of data and corrects for overlapping information among correlated indicators.

The remainder of this study is structured as follows. Section II explains the structure of APRII and data treatment. Section III discusses technical details concerning PCA-based weighting scheme for aggregation. Section IV presents the regional integration index for Asia and the Pacific as well as subregional indexes to cover different geographic groupings for ADB's member economies. For comparison, we also construct regional integration indexes for the European Union (EU), Latin America, and Africa using the same procedure, the results of which are reported in section $V$. Section $\mathrm{VI}$ concludes.

\section{STRUCTURE OF APRII AND DATA TREATMENT}

\section{A. Index Composition and Data Descriptions}

The APRII embodies six dimensions of socioeconomic categories that are fundamental to regional integration. We apportion 26 indicators that measure different aspects of regional integration across these six dimensions and use them to calculate the index. Table 1 reports the dimensions and indicators in each, with data sources. We construct indicators from bilateral data, and they are expressed as a ratio of intraregional sum (or average) to total sum (or average). There are three exceptions: II- $d$ takes a difference between the intraregional and total averages, whereas IV-c and IV-d only have national data available. Most indicators in the table are self-explanatory. We discuss only those warranting elaboration.

\section{Indicator I-c. Intraregional Trade Intensity Index}

For a particular country, the indicator I-c is calculated as a ratio of two trade shares. The numerator is intraregional goods trade/total goods trade, and the denominator is Asia total of goods trade/world total of goods trade, where trade is exports plus imports. It is a standard measure of trade introversion in the literature; a value greater (less) than 1 indicates that the country's goods trade is introverted (extroverted).

\section{Indicator II-a (b). Proportion of Intraregional Cross-Border Equity (Bond) Liabilities to Total Cross-Border Equity (Bond) Liabilities}

A more reliable measure would usually be cross-border holdings of equity and bonds as the holder (creditor) knows which securities are owned, but the issuer (debtor) may not know the holder's residency accurately. However, only 13 of 48 Asian economies report cross-border holdings of equities and bonds, thus rendering it infeasible to adopt them as base data. In its Coordinated Portfolio Investment Survey database, the IMF, fortunately, derives cross-border liabilities for all countries (database participators as well as nonparticipators) using asset data reported by the participating countries. ${ }^{4}$ These bilateral liabilities data of equity and bonds are available for 40 and 39 Asian economies, which we use to construct II-a and II-b.

4 Termed "derived liabilities," the data are reported in Table 8 of the Coordinated Portfolio Investment Survey report. 


\section{Table 1: Asia-Pacific Regional Integration Index: Dimensions and Indicators}

\begin{tabular}{|c|c|c|c|}
\hline Dimension & & Indicator & Data Sources \\
\hline \multirow{4}{*}{$\begin{array}{l}\text { I. } \\
\text { Trade and } \\
\text { Investment } \\
\text { Integration }\end{array}$} & $1-\mathrm{a}$ & Proportion of intraregional goods exports to total goods exports & \multirow{3}{*}{$\begin{array}{l}\text { International Monetary Fund (IMF). Direction of Trade Statistics. } \\
\text { www.imf.org/en/Data (accessed May 2016) }\end{array}$} \\
\hline & $1-\mathrm{b}$ & Proportion of intraregional goods imports to total goods imports & \\
\hline & $\mathrm{I}-\mathrm{c}$ & Intraregional trade intensity index & \\
\hline & $\begin{array}{l}-d \\
\text { I-e }\end{array}$ & $\begin{array}{l}\text { Proportion of intraregional Foreign Direct Investment (FDI) inflows to total FDI inflows } \\
\text { Proportion of intraregional FDI inflows plus outflows to total FDI inflows plus outflows }\end{array}$ & $\begin{array}{l}\text { fDi Markets (Greenfield FDI); and Zephyr Merger and Acquisitions Database } \\
\text { (both accessed June 2016) }\end{array}$ \\
\hline \multirow{4}{*}{$\begin{array}{l}\text { II. } \\
\text { Money and } \\
\text { Finance } \\
\text { Integration }\end{array}$} & $1 \mathrm{II}-\mathrm{a}$ & $\begin{array}{l}\text { Proportion of intraregional cross-border equity liabilities to total cross-border equity } \\
\text { liabilities }\end{array}$ & \multirow[t]{2}{*}{$\begin{array}{l}\text { IMF. Coordinated Portfolio Investment Survey. http://cpis.imf.org (accessed June } \\
\text { 2016) }\end{array}$} \\
\hline & $11-\mathrm{b}$ & Proportion of intraregional cross-border bond liabilities to total cross-border bond liabilities & \\
\hline & $\mathrm{II}-\mathrm{c}$ & Pair-wise dispersion of deposit rates averaged regionally relative to that averaged globally & $\begin{array}{l}\text { CEIC; Haver Analytics; and IMF. International Financial Statistics. } \\
\text { www.imf.org/en/Data (all accessed January 2017) }\end{array}$ \\
\hline & II-d & Pair-wise correlation of equity returns averaged regionally minus that averaged globally & $\begin{array}{l}\text { Bloomberg; Bourse Régionale des Valeurs Mobilières. http://www.brvm.org; CEIC; } \\
\text { Eastern Caribbean Securities Exchange. http://www.ecseonline.com/; Haver } \\
\text { Analytics; South Pacific Stock Exchange. http://www.spse.com.fj; and USZE } \\
\text { Exchange (Uzbekistan). https://www.uzse.uz/ (all accessed December 2016) }\end{array}$ \\
\hline \multirow{4}{*}{$\begin{array}{l}\text { III. } \\
\text { Regional } \\
\text { Value Chain }\end{array}$} & $\mathrm{III}-\mathrm{a}$ & $\begin{array}{l}\text { Ratio between the averaged trade complementarity index over regional trading partners and } \\
\text { the averaged trade complementarity index over all trading partners }\end{array}$ & \multirow[t]{2}{*}{$\begin{array}{l}\text { United Nations Conference on Trade and Development (UNCTAD). } \\
\text { UNCTADstat. http://unctadstat.unctad.org/EN/ (accessed July 2016) }\end{array}$} \\
\hline & III-b & $\begin{array}{l}\text { Ratio between the averaged trade concentration index over regional trading partners and } \\
\text { the averaged trade concentration index over all trading partners }\end{array}$ & \\
\hline & $\mathrm{III}-\mathrm{C}$ & Proportion of intraregional intermediate goods exports to total intraregional goods exports & \multirow{2}{*}{$\begin{array}{l}\text { United Nations. Commodity Trade Database. https://comtrade.un.org/ (accessed } \\
\text { June 2016) }\end{array}$} \\
\hline & III-d & Proportion of intraregional intermediate goods imports to total intraregional goods imports & \\
\hline \multirow{4}{*}{$\begin{array}{l}\text { IV. } \\
\text { Infrastructure } \\
\text { and } \\
\text { Connectivity }\end{array}$} & IV-a & $\begin{array}{l}\text { Ratio between the averaged trade cost over regional trading partners and the averaged trade } \\
\text { cost over all trading partners }\end{array}$ & $\begin{array}{l}\text { World Bank and United Nations Economic and Social Commission for Asia and } \\
\text { the Pacific. Trade Costs Database. www.databank.worldbank.org (accessed June } \\
\text { 2016) }\end{array}$ \\
\hline & IV-b & $\begin{array}{l}\text { Ratio between the averaged liner shipping connectivity index over regional trading partners } \\
\text { and the averaged liner shipping connectivity index over all trading partners }\end{array}$ & $\begin{array}{l}\text { UNCTAD. UNCTADstat. http://unctadstat.unctad.org/EN/ (accessed June } \\
\text { 2016) }\end{array}$ \\
\hline & IV-c & Logistics performance index (overall) & $\begin{array}{l}\text { World Bank. Logistics Performance Index. Ipi.worldbank.org (accessed June } \\
\text { 2016) }\end{array}$ \\
\hline & IV-d & Doing Business Index (overall) & $\begin{array}{l}\text { World Bank. Doing Business 2016. http://www.doingbusiness.org (accessed June } \\
\text { 2016) }\end{array}$ \\
\hline \multirow{4}{*}{$\begin{array}{l}\text { V. } \\
\text { Free } \\
\text { Movement of } \\
\text { People }\end{array}$} & $\mathrm{V}-\mathrm{a}$ & Proportion of intraregional outbound migration to total outbound migration & $\begin{array}{l}\text { United Nations. Department of Economic and Social Affairs, Population Division. } \\
\text { International Migration Stock 2015. http://www.un.org/en (accessed July 2016) }\end{array}$ \\
\hline & $\mathrm{V}-\mathrm{b}$ & Proportion of intraregional tourists to total tourists (inbound plus outbound) & World Tourism Organization. 2016. Tourism Statistics Database. \\
\hline & $\mathrm{V}-\mathrm{c}$ & Proportion of intraregional remittances to total remittances & $\begin{array}{l}\text { World Bank. Migration and Remittances Data. http://www.worldbank.org } \\
\text { (accessed July 2016) }\end{array}$ \\
\hline & V-d & Proportion of other Asian countries that do not require an entry visa & $\begin{array}{l}\text { International Air Transport Association. www.iata.org; national sources; and } \\
\text { Wikipedia. https://en.wikipedia.org (accessed July 2016) }\end{array}$ \\
\hline \multirow{5}{*}{$\begin{array}{l}\text { VI. } \\
\text { Institutional } \\
\text { and Social } \\
\text { Integration }\end{array}$} & $\mathrm{VI}-\mathrm{a}$ & Proportion of other Asian countries that have signed FTAs with & $\begin{array}{l}\text { Design of Trade Agreements (DESTA). www.designoftradeagreements.org } \\
\text { (accessed June 2016) }\end{array}$ \\
\hline & $\mathrm{VI}-\mathrm{b}$ & Proportion of other Asian countries that have an embassy & The Europa World Yearbook 2016. Europa Publications. \\
\hline & $\mathrm{VI}-\mathrm{c}$ & Proportion of other Asian countries that have signed business investment treaties with & $\begin{array}{l}\text { DESTA. www.designoftradeagreements.org; and UNCTAD. Investment Policy } \\
\text { Hub. http://investmentpolicyhub.unctad.org (both accessed June 2016) }\end{array}$ \\
\hline & $\mathrm{VI}-\mathrm{d}$ & Proportion of other Asian countries that have signed double taxation treaties with & $\begin{array}{l}\text { UNCTAD. Investment Policy Hub. http://investmentpolicyhub.unctad.org } \\
\text { (accessed June 2016) }\end{array}$ \\
\hline & $\mathrm{VI}-\mathrm{e}$ & Cultural proximity with other Asian countries relative to that with all other countries & $\begin{array}{l}\text { Centre d'Etudes Prospectives et d'Informations Internationales. www.cepii.fr } \\
\text { (accessed June 2016) }\end{array}$ \\
\hline
\end{tabular}

Source: Authors' compilation. 


\section{Indicator VI-e. Cultural Proximity with Other Asian Countries Relative to that with all Other Countries}

Raw data from the Centre d'Etudes Prospectives et d'Informations Internationales (CEPII) stipulate eight categories for characterizing cultural proximity between countries: each pair of countries that (1) share a national border, (2) adopt a common official language, (3) speak the same language among at least $9 \%$ of their populations, (4) had a mutual colonizer after 1945, (5) have had a colonial link, (6) had a colonial relationship after 1945, (7) currently have a colonial relationship, and (8) were/are the same country. To construct $\mathrm{VI}-\mathrm{e}$, a country receives one point for each affirmative answer in each of the eight categories. Points are then averaged over all Asian and all other regional economies worldwide. The ratio of these two averages yields the final VI-e data.

\section{B. Treatment of Missing Data}

The 48 Asian economies covered by APRII follow the ADB classification:

(i) Central Asia (8 economies): Armenia, Azerbaijan, Georgia, Kazakhstan, Kyrgyz Republic, Tajikistan, Turkmenistan, Uzbekistan.

(ii) East Asia (6 economies): PRC; Hong Kong, China; Japan; Republic of Korea, Mongolia; Taipei,China.

(iii) Southeast Asia (10 economies): Brunei Darussalam, Cambodia, Indonesia, Lao People's Democratic Republic (Lao PDR), Malaysia, Myanmar, Philippines, Singapore, Thailand, Viet Nam.

(iv) South Asia (8 economies): Afghanistan, Bangladesh, Bhutan, India, Maldives, Nepal, Pakistan, Sri Lanka.

(v) The Pacific (14 economies): Cook Islands, Fiji, Kiribati, Marshall Islands, Federated States of Micronesia, Nauru, Palau, Papua New Guinea, Samoa, Solomon Islands, TimorLeste, Tonga, Tuvalu, Vanuatu.

(vi) Oceania (2 economies): Australia, New Zealand.

\section{Countries Covered}

We have a number of missing observations because of the lack of data for a set of countries in our analysis. In order to minimize missing data problem of the overall index and thereby secure computation of minimum set of countries, we adopted a standard imputation method. Appendix $A$ describes the data imputation and analysis procedure in detail.

\section{Year Coverage}

The data are annual for 2013, the latest year for which all required data are available. However, a few exceptions exist. First, the Logistic Performance Index (overall, LPI) in IV-c has no data for 2013, as data are produced only in even years. We therefore construct 2013 data for IV-c by averaging LPI data for 2012 and 2014. Second, bilateral migration data used in $V-a$ are published every 5 years, and therefore data for 2010 and 2015 are available. We linearly interpolate data spanning 2011-2014 and use the interpolated bilateral migration data for 2013 to construct $V$-a. Finally, we found no historic data indicating entry visa requirements to use in the construction of $\mathrm{V}-\mathrm{d}$; we therefore use the data for 2016. 


\section{E. Normalization}

As indicators convey quantitatively different information, some can be incommensurate with others and have different measurement units. Normalization is required prior to aggregation to bring these indicators up to the same standard. Numerous normalization methods, all offering pros and cons, are available (OECD 2008). We adopt min-max rescaling, which has been used in several indicator studies, including the Africa Regional Integration Index, Human Development Index (United Nations), Doing Business Index (World Bank), KOF Index of Globalization (KOF Swiss Economic Institute) (Dreher, Gatson, and Martens 2008), and the Economic Freedom of the World Index (Economic Freedom Network). This procedure normalizes the indicators such that they all range between 0 and 1 . Higher values denote greater regional integration. When higher values of the original indicator denote higher regional integration, the normalization formula for indicator $X_{j}$ is $\left[\left(X_{j}-X_{j, \min }\right) /\left(X_{j, \max }-X_{j, \min }\right)\right]$, where $X_{j, m a x}$ and $X_{j, m i n}$ are maximum and minimum values of that indicator. There are three cases in which higher values of the original indicator lead to lower regional integration: II-c, III-b, and IV-a. ${ }^{5}$ For these indictors, the formula is converted such that $1-\left[\left(X_{j}-X_{j, \min }\right) /\left(X_{j, \max }-X_{j, \min }\right)\right]$.

\section{AGGREGATION SCHEME}

We employ PCA to weigh each component when constructing composite indexes. PCA partitions the variance in a set of variables and uses it to determine weights that maximize the resulting principal component's variation. In effect, the derived principal component is the variable that captures variations in data to the maximum extent possible. PCA has been used to combine sets of indictors into single composites. Examples include the KOF Index of Globalization (KOF Swiss Economic Institute), the Economic Freedom of the World Index (Economic Freedom Network), the Chicago Fed National Activity Index (Federal Reserve Bank of Chicago), and the General Indicator of Science and Technology (National Institute of Science and Technology Policy, Japan). Since PCA is a well-known statistical technique, we only provide a short description and refer the reader to Jackson (1991), Johnson and Wichern (2007), Jolliffe (2002), and Srivastava (2002) for a detailed treatment.

Suppose a data vector comprises four variables, that is, $X=\left(x_{1}, x_{2}, x_{3}, x_{4}\right)$. The principal component, $Z_{i}, i=1,2,3,4$, is defined as

$$
\begin{aligned}
& Z_{1}=a_{1}^{\prime} X=a_{11} x_{1}+a_{21} x_{2}+a_{31} x_{3}+a_{41} x_{4} \\
& Z_{2}=a_{2}^{\prime} X=a_{12} x_{1}+a_{22} x_{2}+a_{32} x_{3}+a_{42} x_{4} \\
& Z_{3}=a_{3}^{\prime} X=a_{13} x_{1}+a_{23} x_{2}+a_{33} x_{3}+a_{43} x_{4} \\
& Z_{4}=a_{4}^{\prime} X=a_{14} x_{1}+a_{24} x_{2}+a_{34} x_{3}+a_{44} x_{4}
\end{aligned}
$$

where the coefficient $a_{i j}$ represents the weight for the ith variable and jth principal component, and $\sum_{i=1}^{4} a_{i 1}^{2}=\sum_{i=1}^{4} a_{i 2}^{2}=\sum_{i=1}^{4} a_{i 3}^{2}=\sum_{i=1}^{4} a_{i 4}^{2}=1$ (normalization).

5 The concentration index in III-b measures the concentration of countries' exports and imports on several products. It is generally thought that if two countries produce diversified products, regional integration would lead to more benefits, as they can complement each other in trade. Under this premise, higher values in the concentration index are associated with lower regional integration. 
Let data vector $X$ have the correlation matrix $\Sigma$ with eigenvalue-eigenvector pairs $\left(\lambda_{1}, e_{1}\right)$, $\left(\lambda_{1}, e_{1}\right),\left(\lambda_{2}, e_{2}\right),\left(\lambda_{3}, e_{3}\right),\left(\lambda_{4}, e_{4}\right)$, where $\lambda_{1} \geq \lambda_{2} \geq \lambda_{3} \geq \lambda_{4}$. ${ }^{6}$ The variance for each principal component is given by the eigenvalue (i.e., $\operatorname{Var}\left(Z_{j}\right)=a_{j}^{\prime} \Sigma a_{j}=\lambda_{j}$ ). PCA seeks linear combinations of the original variables with the maximum variance of $Z_{j}$. Accordingly, the eigenvector corresponding to the largest eigenvalue $\lambda_{1}$ determines $e_{1}=\left(a_{11}, a_{21}, a_{31}, a_{41}\right)^{\prime}$, and the first principal component $Z_{1}=e_{1}^{\prime} X$ explains the largest possible variation in the data. The second principal component $Z_{2}$ is constructed using the eigenvector corresponding to the second-largest eigenvalue $\lambda_{2}$, that is, $Z_{2}=e_{2}^{\prime} X$. It is completely orthogonal to the first principal component and explains additional but less variation than the first component. Subsequent principal components are orthogonal to previous components, and each captures additional but progressively smaller variations in the data. Orthogonality of the principal components implies that changes in one component do not affect other components, which is a desirable feature for composite indexes sometimes. Since total data variance is four (i.e., the number of variables) and equals the sum of eigenvalues, the proportion of total data variance accounted for by the $j$ th principal component is $\lambda_{j} / 4$. Next, we explain how we generated the weights assigned to individual components when constructing their composite indexes.

For illustration, suppose that the first two principal components $\left(Z_{1}\right.$ and $\left.Z_{2}\right)$ are sufficient to characterize the data variation. Correlation coefficients between $X$ and $Z$ are called loadings and are given as $\operatorname{Corr}\left(x_{i}, Z_{j}\right)=\rho_{i j}=e_{i j} \sqrt{\lambda_{j}}, i=1,2,3,4$, and $j=1$ and 2 , where $e_{i j}$ is the ith element of the eigenvector $j$ (For a derivation, see Johnson and Wichern 2007, p. 433). The square of loadings, $\rho_{i j}^{2}$, represents the proportion of variance in variable $x_{i}$, explained by the principal component $Z_{j}$. As $\sum_{i=1}^{4} e_{i 1}^{2}=\sum_{i=1}^{4} e_{i 2}^{2}=1$, the sums of squared loadings of $Z_{1}$ and $Z_{2}$ are $\lambda_{1}$ and $\lambda_{2}$, which are the variances of $Z_{1}$ and $Z_{2}$, respectively. Using this, we normalized the squared loadings to unity sum, that is, $\bar{\rho}_{i j}^{2}=\rho_{i j}^{2} / \lambda_{j}$. We finally constructed $\theta_{j}=\lambda_{j} /\left(\lambda_{1}+\lambda_{2}\right)$, where $j=1$ and 2 , to measure the proportion of explained variance in the data when considering only the first two principal components. $\theta_{1}$ and $\theta_{2}$ are the weights assigned to the respective principal components for aggregation. Hence, the composite index is

$\left(\bar{\rho}_{11}^{2} * \theta_{1}+\bar{\rho}_{12}^{2} * \theta_{2}\right) x_{1}+\left(\bar{\rho}_{21}^{2} * \theta_{1}+\bar{\rho}_{22}^{2} * \theta_{2}\right) x_{2}+\left(\bar{\rho}_{31}^{2} * \theta_{1}+\bar{\rho}_{32}^{2} * \theta_{2}\right) x_{3}+\left(\bar{\rho}_{41}^{2} * \theta_{1}+\bar{\rho}_{42}^{2} * \theta_{2}\right) x_{4}$

6 The covariance matrix can also be used, depending on the nature of data employed. If variances differ widely or measurement units are not commensurate, the covariance matrix will be dominated by variables with large variances. In the empirical part to follow, we use the correlation matrix to prevent these variables from unduly influencing the principal components. 
The weighting scheme is summarized as follows:

\begin{tabular}{|c|cc|cc|c|}
\hline & \multicolumn{2}{|c|}{ Loading } & \multicolumn{2}{c|}{$\begin{array}{c}\text { Squared Loading } \\
\text { (scaled to unit sum) }\end{array}$} & Weight \\
\hline & $Z_{1}$ & $Z_{2}$ & $Z_{1}$ & $Z_{2}$ & \\
\hline$x_{1}$ & $\rho_{11}$ & $\rho_{12}$ & $\bar{\rho}_{11}^{2}$ & $\bar{\rho}_{12}^{2}$ & $\bar{\rho}_{11}^{2} * \theta_{1}+\bar{\rho}_{12}^{2} * \theta_{2}$ \\
$x_{2}$ & $\rho_{21}$ & $\rho_{22}$ & $\bar{\rho}_{21}^{2}$ & $\bar{\rho}_{22}^{2}$ & $\bar{\rho}_{21}^{2} * \theta_{1}+\bar{\rho}_{22}^{2} * \theta_{2}$ \\
$x_{3}$ & $\rho_{31}$ & $\rho_{32}$ & $\bar{\rho}_{31}^{2}$ & $\bar{\rho}_{32}^{2}$ & $\bar{\rho}_{31}^{2} * \theta_{1}+\bar{\rho}_{32}^{2} * \theta_{2}$ \\
$x_{4}$ & $\rho_{41}$ & $\rho_{42}$ & $\bar{\rho}_{41}^{2}$ & $\bar{\rho}_{42}^{2}$ & $\bar{\rho}_{41}^{2} * \theta_{1}+\bar{\rho}_{42}^{2} * \theta_{2}$ \\
\hline Exp. Var. & $\lambda_{1}$ & $\lambda_{2}$ & & \\
Exp/Tot & $\theta_{1}$ & $\theta_{2}$ & & \\
\end{tabular}

\section{EMPIRICAL RESULTS}

First, we apply PCA to each dimension to determine the number of principal components required to capture movements in that dimension. Table 2 reports the results. There is no universally accepted rule as to how many principal components should be retained. Yet, Nardo et al. (2011) observe that the standard practice is to choose components that (1) have associated eigenvalues exceeding 1 (Kaiser criterion), (2) contribute individually to the explanation of total variance by at least $10 \%$, and (3) contribute cumulatively to explain more than $60 \%$ of total variance. We followed these guidelines for the current application. Starting from dimension I in the upper panel, the first principal component corresponding to the largest eigenvalue of 3.04 explains $61 \%$ of total variation in the indicators. The corresponding principal component for the second-largest eigenvalue, which is 1.32 , accounts for an additional $26 \%$ of the total variation. The first two principal components together explain $87 \%$ of the total variation, and they are chosen to represent movements in dimension I. In dimension II, the first two principal components are consistent with the selection criteria and, together, they explain 65\% of total variation in the indicators of dimension II. Results for dimensions III to VI yield the same implication about the number of principal components to adopt. The first two principal components have eigenvalues exceeding 1 and explain at least $74 \%$ of total variation in member indicators. The only exception is that the second-largest eigenvalue in dimension III is 0.92, which is slightly smaller than 1. Taking the results together, we conclude that the first two principal components effectively characterize the movements of indicators in dimensions I through $\mathrm{VI}$, respectively. 
Asia-Pacific Regional Integration Index: Construction, Interpretation, and Comparison | 9

Table 2: Principal Component Analysis and Weights for Aggregation

\begin{tabular}{|c|c|c|c|c|c|c|c|c|c|c|c|c|c|c|c|c|c|}
\hline & \multicolumn{17}{|c|}{ Number of Principal Components } \\
\hline & \multicolumn{5}{|c|}{ Dimension I } & \multicolumn{4}{|c|}{ Dimension II } & \multicolumn{4}{|c|}{ Dimension III } & \multicolumn{4}{|c|}{ Dimension IV } \\
\hline & 1 & 2 & 3 & 4 & 5 & 1 & 2 & 3 & 4 & 1 & 2 & 3 & 4 & 1 & 2 & 3 & 4 \\
\hline Eigenvalue & 3.04 & 1.32 & 0.54 & 0.08 & 0.02 & 1.40 & 1.22 & 0.82 & 0.57 & 2.08 & 0.92 & 0.70 & 0.31 & 1.86 & 1.39 & 0.54 & 0.21 \\
\hline Prop. & 0.61 & 0.26 & 0.10 & 0.02 & 0.01 & 0.35 & 0.30 & 0.21 & 0.14 & 0.52 & 0.23 & 0.17 & 0.08 & 0.47 & 0.34 & 0.13 & 0.06 \\
\hline \multirow[t]{3}{*}{ Cum Prop } & 0.61 & 0.87 & 0.97 & 0.99 & 1.00 & 0.35 & 0.65 & 0.86 & 1.00 & 0.52 & 0.75 & 0.92 & 1.00 & 0.47 & 0.81 & 0.94 & 1.00 \\
\hline & \multicolumn{4}{|c|}{ Dimension $\mathrm{V}$} & \multicolumn{5}{|c|}{ Dimension VI } & \multicolumn{8}{|c|}{ Overall } \\
\hline & 1 & 2 & 3 & 4 & 1 & 2 & 3 & 4 & 5 & & 1 & 2 & 3 & 4 & 5 & 6 & \\
\hline Eigenvalue & 1.90 & 1.05 & 0.66 & 0.39 & 3.00 & 1.27 & 0.43 & 0.19 & 0.12 & & 2.53 & 1.32 & 1.10 & 0.45 & 0.40 & 0.20 & \\
\hline Prop. & 0.48 & 0.26 & 0.16 & 0.10 & 0.60 & 0.25 & 0.09 & 0.04 & 0.02 & & 0.42 & 0.22 & 0.18 & 0.08 & 0.07 & 0.03 & \\
\hline \multirow[t]{3}{*}{ Cum Prop } & 0.48 & 0.74 & 0.90 & 1.00 & 0.60 & 0.85 & 0.94 & 0.98 & 1.00 & & 0.42 & 0.64 & 0.82 & 0.90 & 0.97 & 1.00 & \\
\hline & \multicolumn{17}{|c|}{ Squared loadings } \\
\hline & $\mathrm{I}-\mathrm{a}$ & $\mathrm{I}-\mathrm{b}$ & $\mathrm{I}-\mathrm{C}$ & $\mathrm{I}-\mathrm{d}$ & I-e & $\mathrm{II}-\mathrm{a}$ & II-b & $\mathrm{II}-\mathrm{C}$ & II-d & III-a & III-b & III-C & III-d & $\mathrm{IV}-\mathrm{a}$ & IV-b & $\mathrm{IV}-\mathrm{C}$ & IV-d \\
\hline$Z_{1}$ & 0.54 & 0.65 & 0.78 & 0.48 & 0.59 & 0.49 & 0.52 & 0.02 & 0.37 & 0.72 & 0.18 & 0.43 & 0.75 & 0.06 & 0.23 & 0.85 & 0.72 \\
\hline \multirow[t]{2}{*}{$\mathrm{Z}_{2}$} & 0.14 & 0.12 & 0.20 & 0.49 & 0.37 & 0.25 & 0.01 & 0.75 & 0.21 & 0.01 & 0.79 & 0.09 & 0.03 & 0.68 & 0.49 & 0.04 & 0.18 \\
\hline & $\mathrm{V}-\mathrm{a}$ & $V-b$ & $V-c$ & $V-d$ & $\mathrm{VI}-\mathrm{a}$ & VI-b & $\mathrm{VI}-\mathrm{c}$ & VI-d & VI-e & & I & II & III & IV & V & $\mathrm{VI}$ & \\
\hline $\mathrm{Z}_{1}$ & 0.59 & 0.73 & 0.42 & 0.16 & 0.36 & 0.85 & 0.89 & 0.88 & 0.02 & & 0.16 & 0.27 & 0.56 & 0.48 & 0.56 & 0.50 & \\
\hline $\mathrm{Z}_{2}$ & 0.09 & 0.03 & 0.19 & 0.74 & 0.39 & 0.00 & 0.02 & 0.02 & 0.84 & & 0.12 & 0.35 & 0.07 & 0.24 & 0.28 & 0.26 & \\
\hline \multirow[t]{2}{*}{$\mathrm{Z}_{3}$} & & & & & & & & & & & 0.58 & 0.23 & 0.09 & 0.16 & 0.01 & 0.03 & \\
\hline & \multicolumn{17}{|c|}{ Weights for composite indexes } \\
\hline Indicator & $\mathrm{I}-\mathrm{a}$ & I-b & $\mathrm{I}-\mathrm{C}$ & $\mathrm{I}-\mathrm{d}$ & I-e & II-a & II-b & $\mathrm{II}-\mathrm{C}$ & II-d & III-a & III-b & III-C & III-d & IV-a & IV-b & IV-C & IV-d \\
\hline Weight & 0.156 & 0.177 & 0.226 & 0.221 & 0.220 & 0.280 & 0.202 & 0.294 & 0.224 & 0.241 & 0.324 & 0.175 & 0.260 & 0.229 & 0.222 & 0.274 & 0.275 \\
\hline Indicator & $V-a$ & $V-b$ & $V-c$ & $V-d$ & $\mathrm{VI}-\mathrm{a}$ & VI-b & $\mathrm{VI}-\mathrm{c}$ & VI-d & VI-e & & I & II & III & IV & V & VI & \\
\hline Weight & 0.229 & 0.259 & 0.206 & 0.306 & 0.177 & 0.199 & 0.212 & 0.210 & 0.202 & & 0.175 & 0.171 & 0.146 & 0.178 & 0.169 & 0.161 & \\
\hline
\end{tabular}

Notes: "Prop" and "Cum Prop" rows report the fractions and cumulated fractions of total variation in the data accounted for by each principal component. Values in boldface are the principal components chosen for aggregation.

Source: Authors' calculations. See Table 1 for the data sources. 
Squared loadings of indicators for the chosen principal components appear in the middle of the table. These loadings suggest which indicators are primarily associated with the principal components. In dimension I, for example, all five indicators have sizable loadings on the first principal component $\left(Z_{1}\right)$, while the second principal component $\left(Z_{2}\right)$ has relatively high loadings for I-d and I-e. Hence, the first component reflects comovements in the five indicators, and the second component primarily reflects movements unique to FDI, which were left unexplained by the first component. Dimension II indicates that the first principal component is associated with indicators II-a, II-b, and II$\mathrm{d}$, whereas the second component is dominated by II-c. An implication is that II-c exhibits movements distinctive from the other number indicators. As detailed in section III, squared loadings calculate the weights for combining individual indicators, and the implied weights are reported at the bottom of the table. The indicators appear to be given quantitatively different weights across dimensions. This is consistent with our strategy of not using the arithmetic average (i.e., equal weighting) that has been popularly adopted in the formation of composite indexes.

We now combine the six dimensional composite indexes derived for the construction of an overall APRII index. As before, the first step is to apply PCA, the results of which appear in the panel titled "Overall" in Table 1. The first three principal components have eigenvalues exceeding 1, and individually explain more than $10 \%$ of the variation in the set of six dimensional indexes. Together, they account for $83 \%$ of total variation, with marginal contributions from the remaining three principal components. We choose the first three principal components, as per the selection criteria. Squared loadings for the chosen principal components are reported in the middle of the table. The first principal component exhibits high loadings for dimensions III through IV, whereas the second and third components are primarily associated with dimensions II and I, respectively. As reported at the bottom of the table, these findings are reflected in the final weights used to combine the dimensional indexes. Dimension IV has the highest weight (0.178), followed by dimensions I and II. The least weight is given to dimension III (0.146). For easy reference, Table 3 collects all the weights used in the construction of dimensional and overall indexes. Nardo et al. (2011) recommend a positive correlation of 0.4 to 0.8 between the dimensional and overall indexes. Our results coincide with their criterion, as the corresponding cross correlations range from 0.53 to $0.76 .^{7}$

Figure 1 depicts the overall index of Asian regional integration for 24 economies. Note that the overall index is not available for other member countries, since some of the dimensional indexes could not be generated due to an absence of data. Among the 24 reported, Singapore is the most regionally integrated, exhibiting the highest score (0.63). The second- and third-highest are Malaysia (0.614) and Thailand (0.591). The PRC and Japan, the world's second- and third-largest economies, ranked sixth and ninth. Thirteen Asian economies outperform the regional average (0.473). The Central Asian countries exhibit lower regional integration than other Asian economies.

\footnotetext{
7 Cross correlations of the overall index with each dimension's index are 0.53 (I), 0.55 (II), 0.65 (III), 0.67 (IV), 0.76 (V),
} and $0.67(\mathrm{VI})$. 
Table 3: Weight Summary for Asia-Pacific Regional Integration Index

\begin{tabular}{|c|c|c|}
\hline \multicolumn{2}{|c|}{ Dimensions and Indicators } & Weights \\
\hline \multicolumn{2}{|r|}{ I. Trade and Investment Integration } & 0.1749 \\
\hline $\mathrm{I}-\mathrm{a}$ & Proportion of intraregional goods exports to total goods exports & 0.1563 \\
\hline $\mathrm{I}-\mathrm{b}$ & Proportion of intraregional goods imports to total goods imports & 0.1771 \\
\hline I-c & Intraregional trade intensity index & 0.2255 \\
\hline I-d & Proportion of intraregional FDI inflows to total FDI inflows & 0.2211 \\
\hline I-e & Proportion of intraregional FDI inflows plus outflows to total FDI inflows plus outflows & 0.2200 \\
\hline \multicolumn{2}{|r|}{ II. Money and Finance Integration } & 0.1705 \\
\hline II-a & Proportion of intraregional cross-border equity liabilities to total cross-border equity liabilities & 0.2796 \\
\hline II-b & Proportion of intraregional cross-border bond liabilities to total cross-border bond liabilities & 0.2021 \\
\hline II-c & Pairwise dispersion of deposit rates averaged regionally relative to that averaged globally & 0.2945 \\
\hline II-d & Pairwise correlation of equity returns averaged regionally minus that averaged globally & 0.2238 \\
\hline \multicolumn{2}{|r|}{ III. Regional Value Chain } & 0.1460 \\
\hline III-a & $\begin{array}{l}\text { Ratio between the averaged trade complementarity index over regional trading partners and the averaged trade complementarity index over all trading } \\
\text { partners }\end{array}$ & 0.2407 \\
\hline III-b & Ratio between the averaged trade concentration index over regional trading partners and the averaged trade concentration index over all trading partners & 0.3240 \\
\hline III-c & Proportion of intraregional intermediate goods exports to total intraregional goods exports & 0.1751 \\
\hline III-d & Proportion of intraregional intermediate goods imports to total intraregional goods imports & 0.2602 \\
\hline \multicolumn{2}{|r|}{ IV. Infrastructure and Connectivity } & 0.1783 \\
\hline IV-a & Ratio between the averaged trade cost over regional trading partners and the averaged trade cost over all trading partners & 0.2293 \\
\hline IV-b & $\begin{array}{l}\text { Ratio between the averaged liner shipping connectivity index over regional trading partners and the averaged liner shipping connectivity index over all } \\
\text { trading partners }\end{array}$ & 0.2219 \\
\hline IV-c & Logistics Performance Index (overall) & 0.2739 \\
\hline & Doing Business Index (overall) & 0.2749 \\
\hline \multicolumn{2}{|r|}{ V. Free Movement of People } & 0.1692 \\
\hline V-a & Proportion of intraregional outbound migration to total outbound migration & 0.2293 \\
\hline V-b & Proportion of intraregional tourists to total tourists (inbound plus outbound) & 0.2584 \\
\hline$V-c$ & Proportion of intraregional remittances to total remittances & 0.2064 \\
\hline V-d & Proportion of other Asian countries that do not require an entry visa & 0.3059 \\
\hline \multicolumn{2}{|r|}{ VI. Institutional and Social Integration } & 0.1611 \\
\hline $\mathrm{VI}-\mathrm{a}$ & Proportion of other Asian countries that have signed FTAs with & 0.1771 \\
\hline VI-b & Proportion of other Asian countries that have an embassy & 0.1991 \\
\hline $\mathrm{VI}-\mathrm{c}$ & Proportion of other Asian countries that have signed business investment treaties with & 0.2118 \\
\hline VI-d & Proportion of other Asian countries that have signed double taxation treaties with & 0.2098 \\
\hline VI-e & Cultural proximity with other Asian countries relative to that with all other countries & 0.2022 \\
\hline
\end{tabular}

$\mathrm{FDI}=$ foreign direct investment, $\mathrm{FTAs}=$ free trade agreements

Source: Authors' calculations. See Table 1 for the data sources. 
Figure 1: Asia Regional Integration Index: Overall

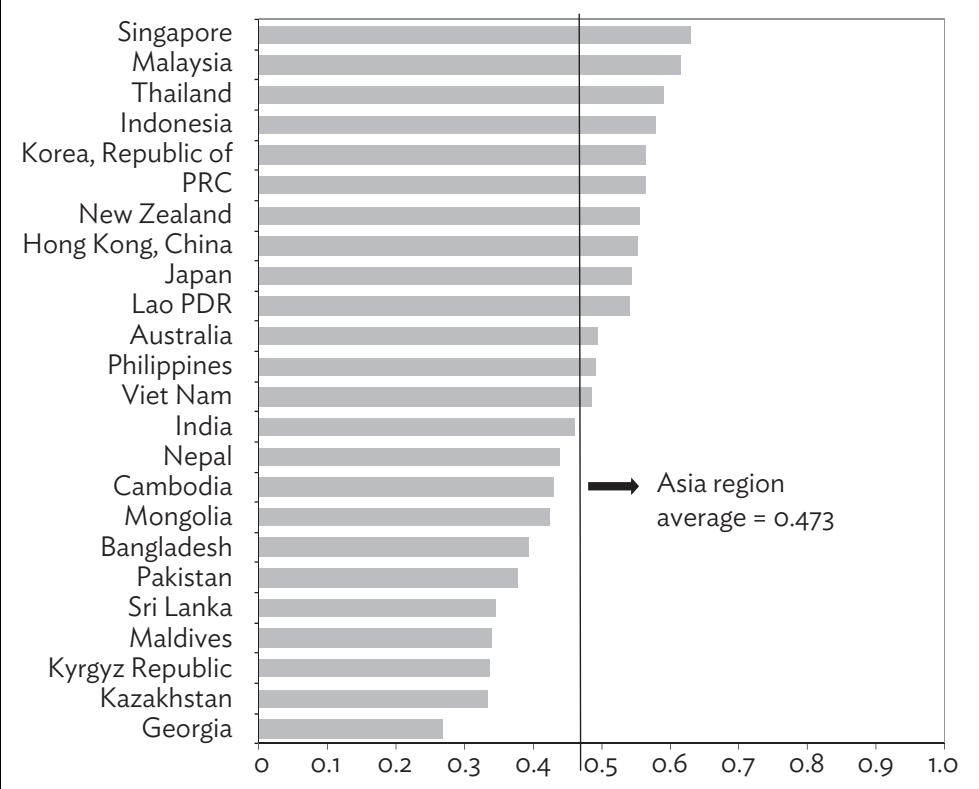

Lao PDR = Lao People's Democratic Republic, PRC = People's Republic of China. Source: Authors' calculations. See Table 1 for the data sources.

Figure 2 illustrates each dimensional index, in which economies appear in order of their overall ranking in Figure 1. Singapore, the top performer, scores high across dimensions, particularly with free movement of people. Yet, regional money and finance integration is weaker than the other dimensions, and this may reflect that Singapore is a global financial center and more globally integrated than regionally. Both Hong Kong, China and Japan are equally renowned global financial centers and they also exhibit a low score for regional money and finance integration. Many manufacturing countries in Asia attain high scores for regional value chain, probably driven by strong vertical industrial integration. Indeed, about $53 \%$ of total intraregional trade (exports plus imports) are intermediate goods. The PRC and Japan are key players in Asia's regional value chain. Nevertheless, these countries exhibit low levels of regional trade and investment integration (0.377 and 0.376 ), reflecting comparatively small proportions of intraregional trade to total trade (0.462 and 0.538$)$ and intraregional FDI (inflows plus outflows) to total FDI (0.367 and 0.435). Overall, trade and FDI in the PRC and Japan seem less regionally oriented than one may think.

Figure $3 a$ shows the overall regional integration indexes of selected subregions in Asia. ${ }^{8}$ Southeast Asia ranks highest, with an average of 0.545, and its maximum and minimum values are 0.63 and 0.429. This is perhaps unsurprising, as all Southeast Asian countries belong to ASEAN, which has been fostering intergovernmental cooperation and facilitating economic integration among its members for decades. These results also appear in Figure 1. The top four countries and half of the top 10 countries in the overall rankings are in Southeast Asia. The second and third go to East Asia and Oceania, with respective averages of 0.529 and 0.524 . South Asia follows, and Central Asia ranks last, with maximum value of 0.336 far below Asia's regional average.

8 The subregions are defined according to the ADB classification. The indexes are averaged over countries in the respective subregions. 


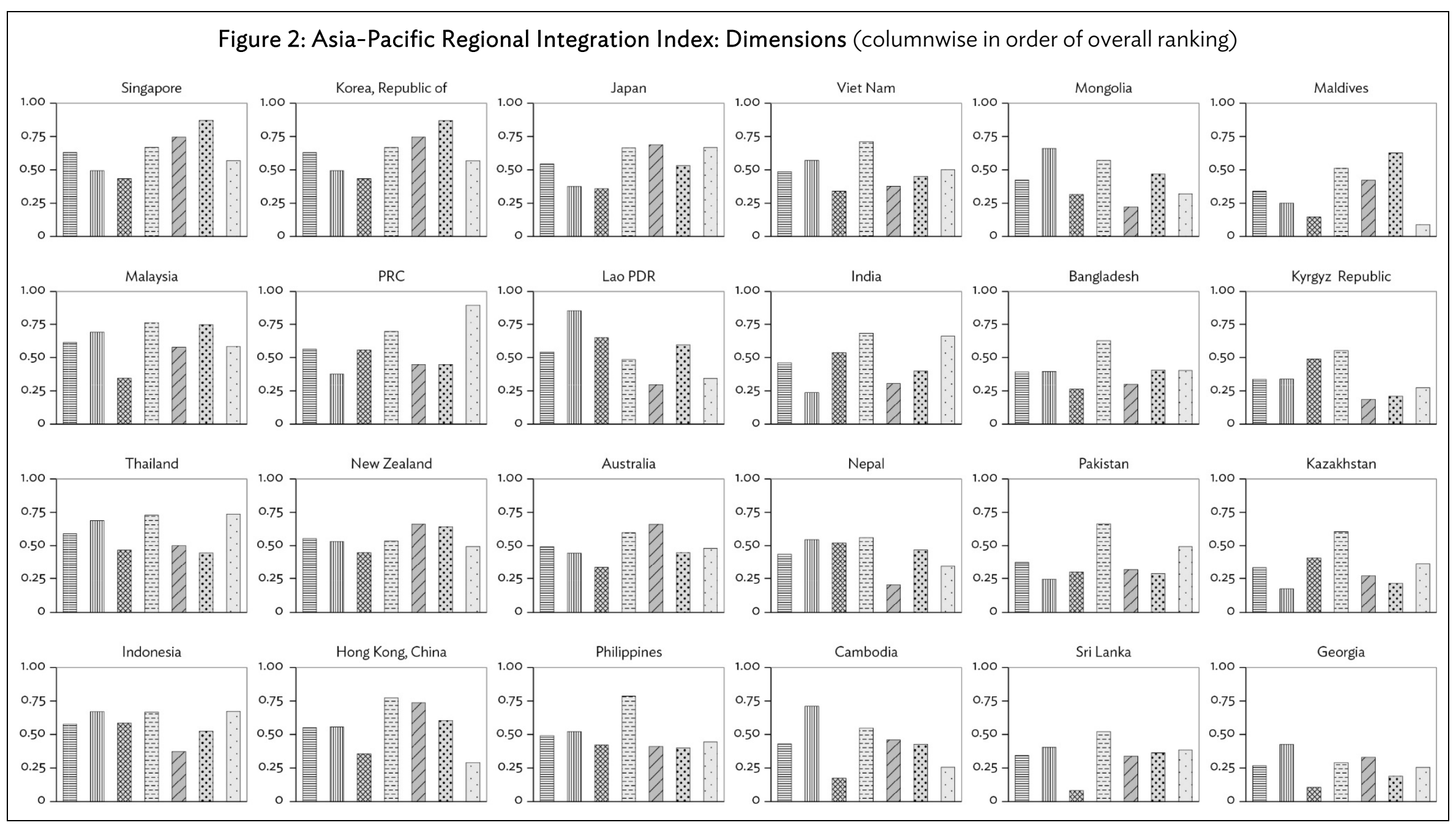


14 | ADB Economics Working Paper Series No. 511

Figure 2 continued

Afghanistan
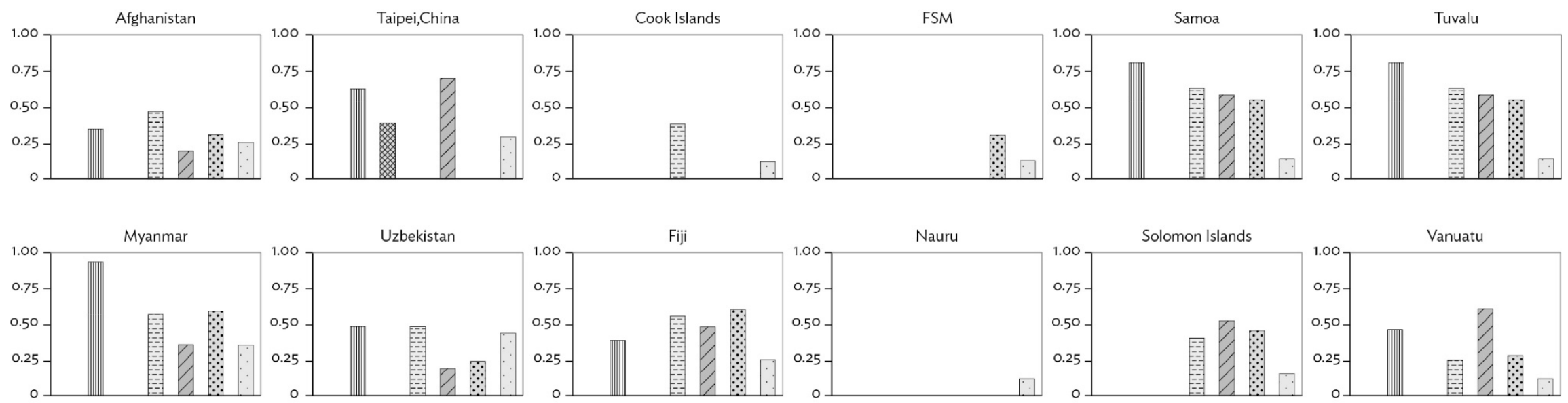

Fiji
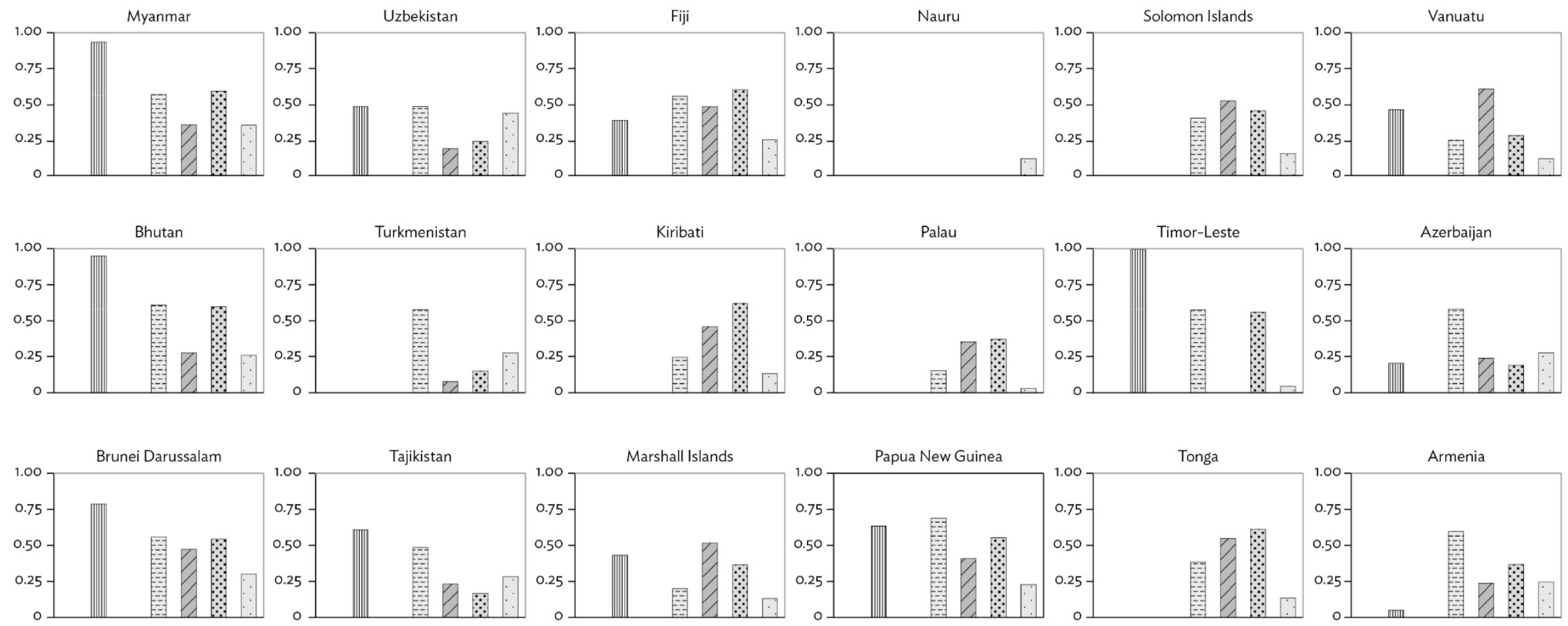

望 Overall

एس] Trade and investment integration

Money and finance integration

Regional value chain

$\nabla /$ Infrastructure and connectivity

Free movement of people $\therefore$ Institutional and social integration

FSM = Federated States of Micronesia, Lao PDR = Lao People's Democratic Republic, PRC $=$ People's Republic of China

Source: Authors' calculations. See Table 1 for the data sources. 
Figure 3a: Overall Integration Index by Subregion

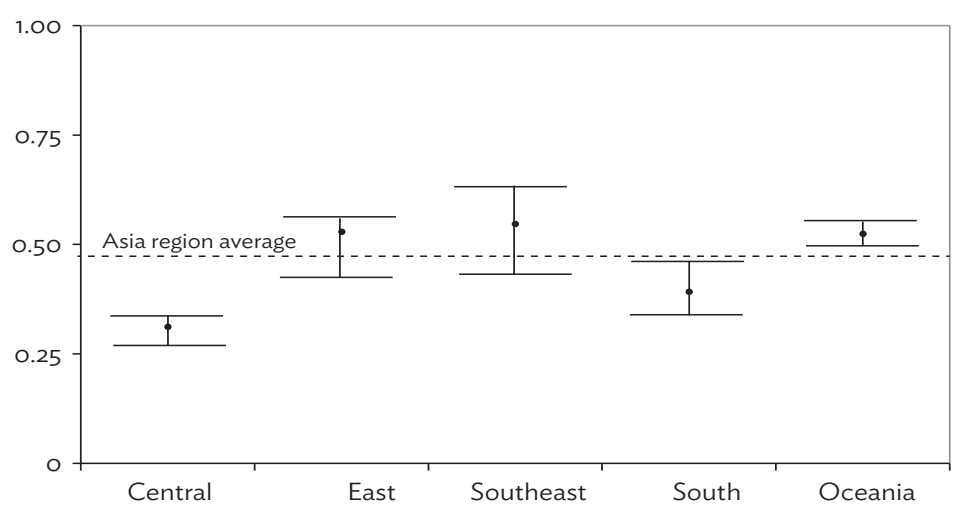

Notes: For each subregion in Figure 3a, maximum (upper line), average (thick dot), and minimum (lower line) values of the overall index are reported. The horizontal line denotes Asia's regional average of 0.473 .

Source: Authors' calculations. See Table 1 for the data sources.

Figure 3b illustrates the six dimensional composite indexes for these subregions plus the Pacific. ${ }^{9}$ Figure $3 c$ presents the summary. Southeast Asia scores high on all dimensions, with averages unanimously above corresponding averages for Asia. Trade and investment integration and free movement of people are particularly strong dimensions. East Asia earns its highest scores for regional value chain and institutional and social integration. However, it performs relatively weakly in trade and investment integration, perhaps because goods trade and FDI in East Asia are more global than regional, as discussed earlier. South Asia is particularly weak in infrastructure and connectivity, whereas the Pacific scores lowest for regional value chain and institutional and social integration. Central Asia fares most poorly, with all averages for the dimensional indexes below the corresponding averages for Asia.

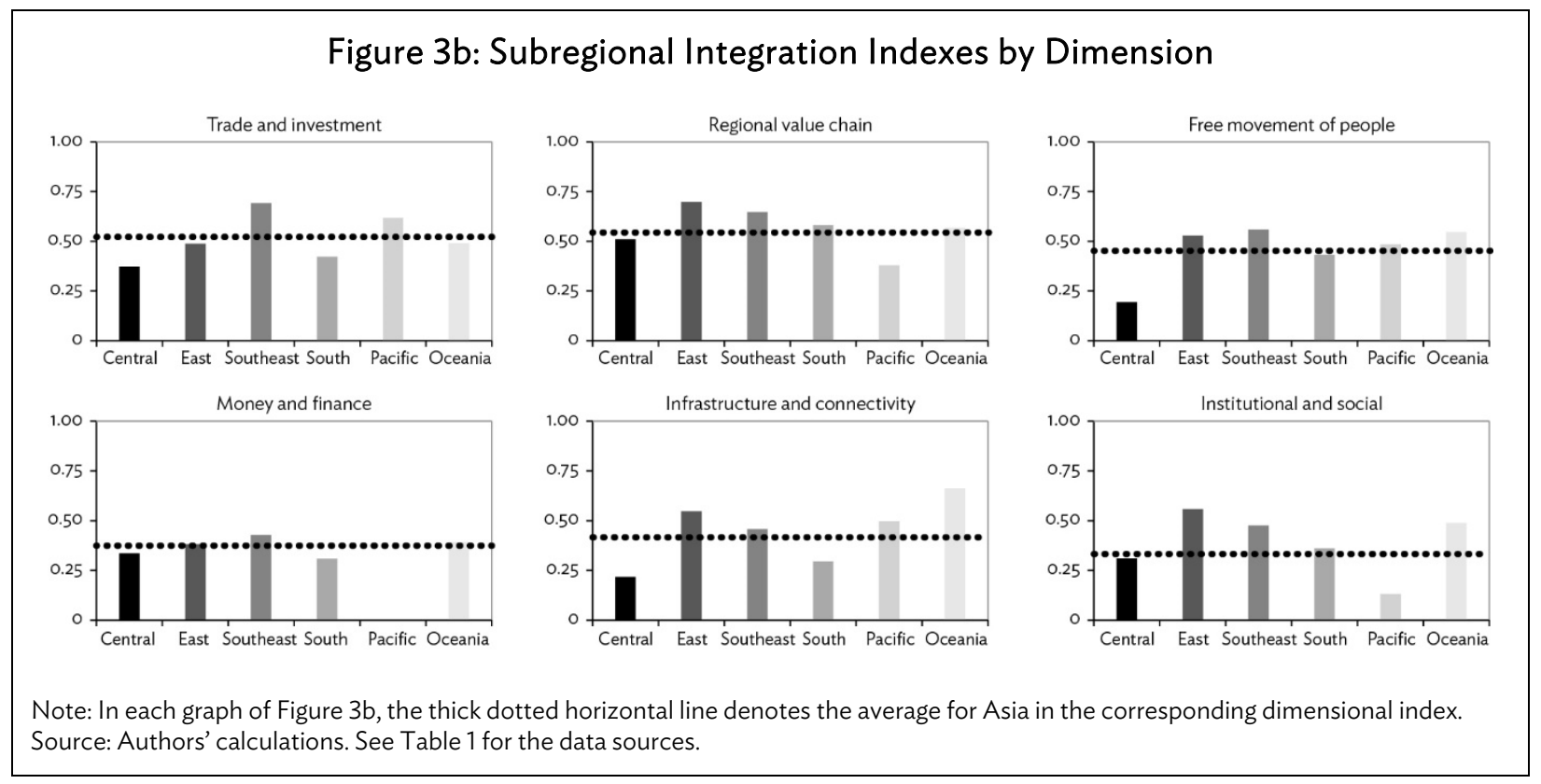

9 Due to lack of data, none of the countries in the Pacific produces the composite index of dimension II or the overall index. 


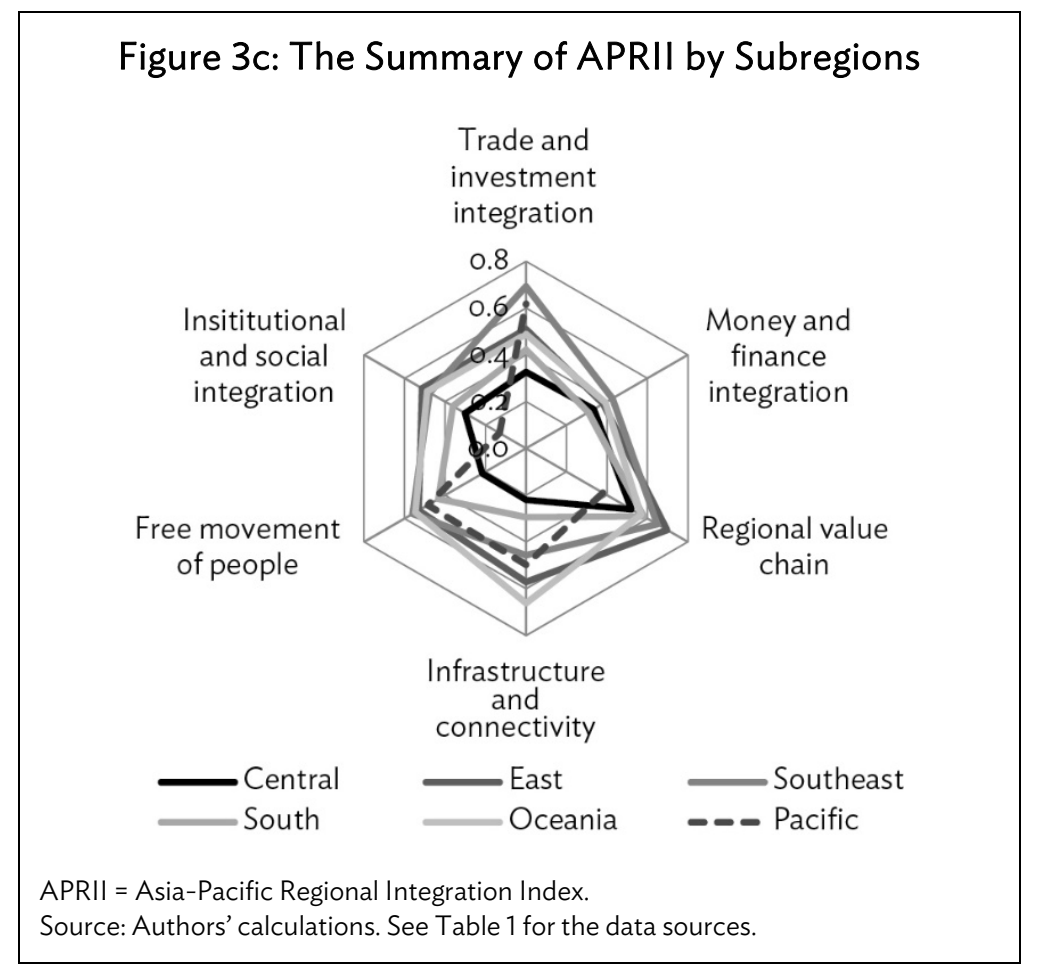

\section{COMPARISONS TO OTHER REGIONS}

For comparison, we construct regional integration indexes for the EU, Latin America, and Africa. Appendix B shows the list of relevant countries. Of particular interest is the EU, where regional integration is considered highly advanced perhaps based on the world's most formal legal and institutional framework for economic integration. Latin America and Africa have been also pursuing regional integration as an important strategy to promote economic growth and inclusive development. ${ }^{10}$ Comparing these regions can help in objectively judging the status of Asian regional integration and prioritizing areas where progress may need to be accelerated. For compatibility, the makeup of the indexes, data descriptions, and statistical procedures are the same as APRII.

Table 4 summarizes the results of PCA for the EU, Latin America, and Africa. ${ }^{11}$ The same criteria apply for choosing the number of principal components that effectively represent data movements. All three regions appear to endorse two principal components, as in Asia, across

10 As noted in the introduction, Africa has its own regional integration index, Africa Regional Integration Index, developed through collaboration among the African Union Commission, African Development Bank, and Economic Commission for Africa (2016b). The comparison between the Africa Regional Integration Index and our index for Africa is particularly relevant because they adopt a different method of aggregation to construct composite indexes. However, some issues render this comparison difficult and unreliable. The Africa Regional Integration Index is organized into eight regional economic communities (RECs), which form the building blocks for the African Economic Community in the Abuja Treaty signed in 1991. The main problem is that no overall country rankings exist, although they are expected to appear. Furthermore, indicators are normalized on REC-by-REC basis, so that ranges of variation differ depending on the REC. Moreover, over $70 \%$ of the African countries belong to more than one REC and therefore have multiple scores. That is, country $A$ outperforms country $B$ in some RECs and vice versa in other RECs. Because of these reasons, we do not compare the two indexes here.

11 For brevity, the full results are not reported here but are available upon request. 
dimensions. A notable exception is dimension VI for the EU, for which PCA is inapplicable. ${ }^{12}$ Similar results are obtainable for PCAs of the six dimensional composite indexes, as reported in the panel titled "Overall." For all three regions, we chose three principal components to summarize movements in the dimensions. Overall, empirical results credit the makeup of the index as they are robust across regions, barring two minor instances in the EU. Finally, the implied weights assigned to dimensional indexes to construct their overall indexes are reported at the bottom. Weights vary by region. For example, the EU shows the highest weight in dimension II (0.184), whereas weights for Latin America and Africa are highest in dimensions IV (0.209) and I (0.197). The lowest weights are found in dimensions $\mathrm{V}$ (0.133), III (0.111), and VI (0.135) for these regions. The weights also differ from Asia, where dimension $\mathrm{VI}$ is highest at 0.178 and dimension III is lowest at 0.146 . In addition, the three regions exhibit more variations in weight than Asia does.

As outlined in section II, the min-max normalization was made based on data within the region. Therefore, Asia, the EU, Latin America, and Africa take their respective maximum and minimum in the normalization. This is a standard approach to measure and compare the integration levels of member countries in the region. However, it is possible that each region have very different maximum and minimum values. Then, the composite indexes constructed can have different bases depending on regions, and this may make comparing between regions obscure and unappealing. To have a more direct comparison between different regions, probably a better way would be to normalize indicators based on all regions together. In other worlds, normalize indicators using world maximum and minimum values for all regions. An obvious advantage is that the constructed indexes can be compared at the same base. We apply this worldwide normalization; however, the number of principal components and all weights are assumed to be the same as before to render the comparison as straightforward as possible. ${ }^{13}$

12 The EU has established plurilateral agreements among its members with respect to FTAs and business investment treaties. As such, indicators $\mathrm{VI}-\mathrm{a}$ and $\mathrm{VI}$-c have the same value (perfect scores) across EU countries and yield no cross correlation to other indicators. Since this makes the PCA inapplicable, the composite index for dimension VI is created by simply averaging the member indicators (i.e., equal weighting).

13 Canada and the United States are included when calculating the world maximum and minimum. 
Table 4: Principal Component Analysis and Weights for Aggregation: EU, Latin America, and Africa

\begin{tabular}{|c|c|c|c|c|c|c|c|c|c|c|c|c|c|c|c|c|c|}
\hline & \multicolumn{17}{|c|}{ Number of principal components } \\
\hline & \multicolumn{17}{|c|}{ EU } \\
\hline & \multicolumn{5}{|c|}{ Dimension I } & \multicolumn{4}{|c|}{ Dimension II } & \multicolumn{4}{|c|}{ Dimension III } & \multicolumn{4}{|c|}{ Dimension IV } \\
\hline & 1 & 2 & 3 & 4 & 5 & 1 & 2 & 3 & 4 & 1 & 2 & 3 & 4 & 1 & 2 & 3 & 4 \\
\hline Eigenvalue & 3.13 & 1.19 & 0.52 & 0.14 & 0.01 & 1.29 & 1.14 & 0.95 & 0.61 & 2.10 & 1.16 & 0.50 & 0.24 & 2.16 & 0.87 & 0.68 & 0.29 \\
\hline Prop. & 0.63 & 0.24 & 0.10 & 0.02 & 0.01 & 0.32 & 0.29 & 0.24 & 0.15 & 0.52 & 0.29 & 0.13 & 0.06 & 0.54 & 0.22 & 0.17 & 0.07 \\
\hline \multirow[t]{3}{*}{ Cum Prop } & 0.63 & 0.87 & 0.97 & 0.99 & 1.00 & 0.32 & 0.61 & 0.85 & 1.00 & 0.52 & 0.81 & 0.94 & 1.00 & 0.54 & 0.76 & 0.93 & 1.00 \\
\hline & \multicolumn{4}{|c|}{ Dimension V } & \multicolumn{5}{|c|}{ Dimension VI } & \multicolumn{8}{|c|}{ Overall } \\
\hline & 1 & 2 & 3 & 4 & 1 & 2 & 3 & 4 & 5 & & 1 & 2 & 3 & 4 & 5 & 6 & \\
\hline Eigenvalue & 2.04 & 1.21 & 0.48 & 0.26 & - & - & - & - & - & & 2.63 & 1.27 & 0.88 & 0.59 & 0.41 & 0.22 & \\
\hline Prop. & 0.51 & 0.30 & 0.12 & 0.07 & - & - & - & - & - & & 0.44 & 0.21 & 0.15 & 0.10 & 0.07 & 0.03 & \\
\hline \multirow[t]{4}{*}{ Cum Prop } & 0.51 & 0.81 & 0.93 & 1.00 & - & - & - & - & - & & 0.44 & 0.65 & 0.80 & 0.90 & 0.97 & 1.00 & \\
\hline & \multicolumn{17}{|c|}{ Latin America } \\
\hline & \multicolumn{5}{|c|}{ Dimension I } & \multicolumn{4}{|c|}{ Dimension II } & \multicolumn{4}{|c|}{ Dimension III } & \multicolumn{4}{|c|}{ Dimension IV } \\
\hline & 1 & 2 & 3 & 4 & 5 & 1 & 2 & 3 & 4 & 1 & 2 & 3 & 4 & 1 & 2 & 3 & 4 \\
\hline Eigenvalue & 2.39 & 1.97 & 0.56 & 0.05 & 0.02 & 1.59 & 1.00 & 0.91 & 0.51 & 1.74 & 1.05 & 0.69 & 0.51 & 1.76 & 1.06 & 0.86 & 0.32 \\
\hline Prop. & 0.48 & 0.39 & 0.11 & 0.01 & 0.01 & 0.40 & 0.25 & 0.22 & 0.13 & 0.44 & 0.26 & 0.17 & 0.13 & 0.44 & 0.26 & 0.22 & 0.08 \\
\hline \multirow[t]{3}{*}{ Cum Prop } & 0.48 & 0.87 & 0.98 & 0.99 & 1.00 & 0.40 & 0.65 & 0.87 & 1.00 & 0.44 & 0.70 & 0.87 & 1.00 & 0.44 & 0.70 & 0.92 & 1.00 \\
\hline & \multicolumn{4}{|c|}{ Dimension V } & \multicolumn{5}{|c|}{ Dimension VI } & \multicolumn{8}{|c|}{ Overall } \\
\hline & 1 & 2 & 3 & 4 & 1 & 2 & 3 & 4 & 5 & & 1 & 2 & 3 & 4 & 5 & 6 & \\
\hline Eigenvalue & 1.85 & 1.01 & 0.89 & 0.24 & 2.75 & 1.20 & 0.52 & 0.36 & 0.16 & & 1.85 & 1.51 & 1.03 & 0.81 & 0.57 & 0.24 & \\
\hline Prop. & 0.46 & 0.25 & 0.23 & 0.06 & 0.55 & 0.24 & 0.10 & 0.07 & 0.04 & & 0.31 & 0.25 & 0.17 & 0.13 & 0.10 & 0.04 & \\
\hline Cum Prop & 0.46 & 0.71 & 0.94 & 1.00 & 0.55 & 0.79 & 0.89 & 0.96 & 1.00 & & 0.31 & 0.56 & 0.73 & 0.86 & 0.96 & 1.00 & \\
\hline
\end{tabular}


Table 4 continued

\begin{tabular}{|c|c|c|c|c|c|c|c|c|c|c|c|c|c|c|c|c|c|}
\hline & \multicolumn{17}{|c|}{ Africa } \\
\hline & \multicolumn{5}{|c|}{ Dimension I } & \multicolumn{4}{|c|}{ Dimension II } & \multicolumn{4}{|c|}{ Dimension III } & \multicolumn{4}{|c|}{ Dimension IV } \\
\hline & 1 & 2 & 3 & 4 & 5 & 1 & 2 & 3 & 4 & 1 & 2 & 3 & 4 & 1 & 2 & 3 & 4 \\
\hline Eigenvalue & 3.12 & 1.42 & 0.42 & 0.03 & 0.01 & 1.46 & 1.17 & 0.85 & 0.52 & 1.57 & 1.11 & 0.84 & 0.49 & 1.78 & 1.10 & 0.70 & 0.42 \\
\hline Prop. & 0.63 & 0.28 & 0.08 & 0.01 & 0.00 & 0.37 & 0.29 & 0.21 & 0.13 & 0.39 & 0.28 & 0.21 & 0.12 & 0.45 & 0.27 & 0.17 & 0.11 \\
\hline \multirow[t]{3}{*}{ Cum Prop } & 0.63 & 0.91 & 0.99 & 1.00 & 1.00 & 0.37 & 0.66 & 0.87 & 1.00 & 0.39 & 0.67 & 0.88 & 1.00 & 0.45 & 0.72 & 0.89 & 1.00 \\
\hline & \multicolumn{4}{|c|}{ Dimension V } & \multicolumn{5}{|c|}{ Dimension VI } & \multicolumn{8}{|c|}{ Overall } \\
\hline & 1 & 2 & 3 & 4 & 1 & 2 & 3 & 4 & 5 & & 1 & 2 & 3 & 4 & 5 & 6 & \\
\hline Eigenvalue & 1.90 & 0.98 & 0.71 & 0.41 & 1.85 & 1.31 & 0.78 & 0.62 & 0.44 & & 2.09 & 1.26 & 1.08 & 0.68 & 0.62 & 0.27 & \\
\hline Prop. & 0.47 & 0.24 & 0.18 & 0.11 & 0.37 & 0.26 & 0.16 & 0.12 & 0.09 & & 0.35 & 0.21 & 0.18 & 0.11 & 0.10 & 0.05 & \\
\hline Cum Prop & 0.47 & 0.71 & 0.89 & 1.00 & 0.37 & 0.63 & 0.79 & 0.91 & 1.00 & & 0.35 & 0.56 & 0.74 & 0.85 & 0.95 & 1.00 & \\
\hline
\end{tabular}

Weights for Overall Regional Integration Index

\begin{tabular}{l|cccccc}
\hline Region & I & II & III & IV & V \\
\hline EU & 0.159 & 0.184 & 0.180 & 0.177 & 0.133 \\
Latin America & 0.189 & 0.139 & 0.111 & 0.209 & 0.180 \\
Africa & 0.197 & 0.140 & 0.163 & 0.185 & 0.172 \\
\hline
\end{tabular}

Notes: "Prop" and "Cum Prop" rows report the fractions and cumulated fractions of total variation in the data accounted for by each principal component. Values in boldface are the principal components chosen for aggregation.

Source: Authors' calculations. See Table 1 for the data sources. 
Figure 4 (first panel) shows the averaged overall regional integration index for the EU, Latin America, and Africa, alongside Asia. As expected, the EU outperforms all other regions, with an average of 0.661 . Asia comes second, where the overall index has an average of 0.416 but is $37 \%$ below the EU. Latin America performs slightly weaker than Asia, with an average of 0.387, and Africa closely follows, with an average of 0.355 . Table 5 lists world rankings of the economies on the overall regional integration index. This highlights how strongly the EU is integrated regionally. All $27 \mathrm{EU}$ countries stand on top without a single exception. Poland is world number 1 , and Cyprus, the least regionally integrated country in the EU, ranks 27th. Singapore, ranking 28th, scores highest (0.541) among non-EU countries. Other top 10 performers in Asia attain high scores, with rankings between 29th and 39th. Swaziland and Paraguay are 30th and 38th, marking the top rankers for Africa and Latin America.

Figure 4 also presents the dimensional composite indexes for four regions, and the results are compactly summarized in Figure 5. The EU attains highest scores on all dimensions. The dominance is particularly pronounced in institutional and social integration, with its integration score in that area at least three times larger than that of other regions. Only Asia's trade and investment integration is comparable in magnitude to that of the EU. Asia also ranks second in money and finance integration, and free movement of people. Latin America beats Asia as well as Africa for the remaining dimensions of regional value chain, infrastructure and connectivity, and institutional and social integration.

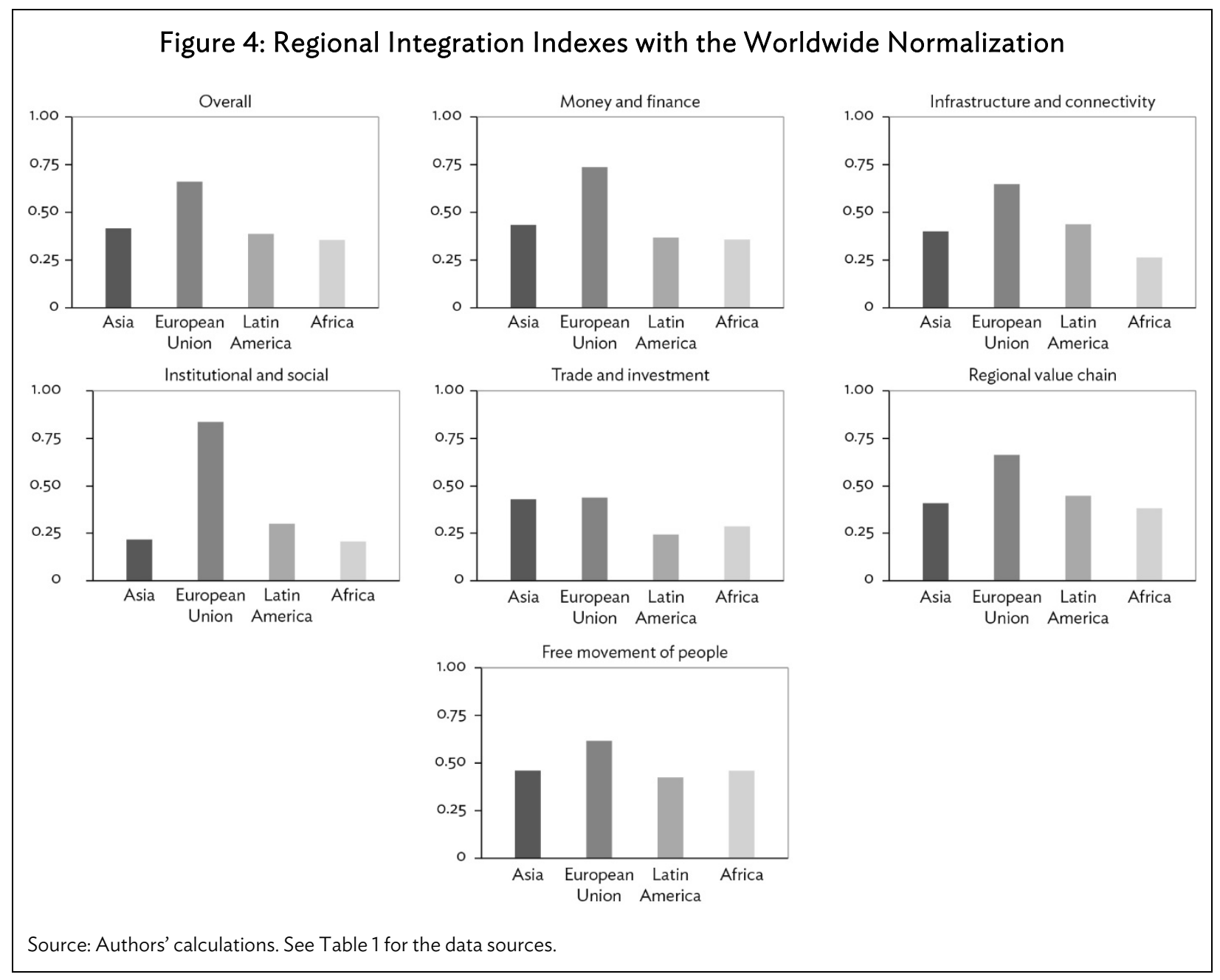




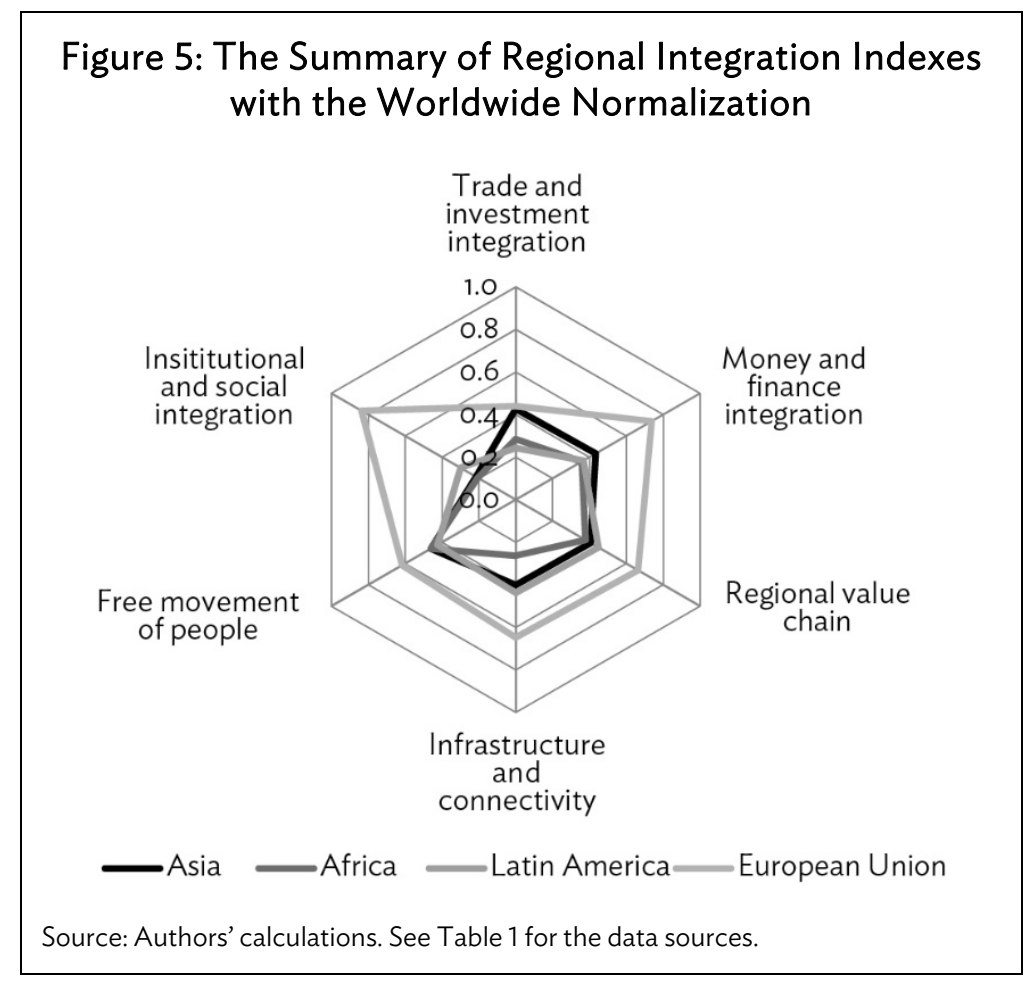

\section{CONCLUSION}

Over recent decades, regional integration has been put forth as a strategy for sustained growth and inclusive development. Asia is no exception; its member countries have instituted numerous initiatives and policies to achieve shared goals through deeper regional integration. There have also been some efforts to monitor and evaluate the countries' progress against these set goals (e.g., Naeher 2015). However, lack of indicators that are broad based and comprehensive to capture multiple dimensions of regional integration have limited our ability to understand the regional integration dynamics and assess its progress. To address this deficiency, the current study proposes a regional integration index for Asia and the Pacific, APRII, that can assess the state of regional integration for individual economies and their subregional groups in various aspects of integration, identify strengths and weaknesses, and allow policy makers to track progress in a comprehensive and systematic way.

APRII aggregates 26 indicators in six dimensions: trade and investment integration, money and finance integration, regional value chain, infrastructure and connectivity, free movement of people, and institutional and social integration. These 26 indicators may not be exhaustive, but represent key variables of regional integration across the six dimensions. Two sets of indexes are derived: six dimensional indexes and their overall index. Both indexes are constructed by weight-averaging their respective components, with weights determined by PCA. We constructed composite indexes in conformity with guidelines enumerated in the OECD (2008).

In overall rankings, Singapore emerges as most regionally integrated, followed by Malaysia, Thailand, and Indonesia. All are members of ASEAN, which was established in 1969 to promote intergovernmental cooperation and facilitate economic integration among its members. Southeast Asia as a region stands at the top among six subregions of the Asia and Pacific on regional integration levels. Southeast Asia shows particularly strong integration in trade and investment, money and 
finance integration, and free movement of people. The PRC and Japan, the world's second- and thirdlargest economies, rank sixth and ninth, respectively. These economies are more globally integrated in terms of their trade and investment, presenting relatively low scores for trade and investment integration due to relatively small shares of intraregional trade and FDI in their total trade and FDI. East Asia, including those two countries, ranks second overall for regional integration, closely followed by Oceania. Central Asia is last in the rankings, with all dimensional and overall indexes scoring below corresponding averages for Asia.

In this study, we also constructed regional integration indexes for the EU, Latin America, and Africa for comparison. The EU was considered especially interesting as a point of comparison because it is arguably the world's most integrated region. As expected, it considerably outperforms Asia as well as the other two regions. On the six dimensions, only Asia's trade and investment integration is comparable in magnitude to that of the EU. Institutional and social integration is particularly weak in Asia. Overall, Asia's current regional integration is not exemplary, even compared to Latin America and Africa. This result may be somewhat surprising, given the strong initiatives and policies that Asian countries have advanced to deepen regional integration. One explanation may be that Asia has focused more on trade integration and relegated other dimensions to secondary importance. In contrast, regional integration is a multidimensional phenomenon. Our empirical results suggest that other dimensions should be given as much attention as, if not more, trade integration in the establishment of Asia's regional integration. The comparison with other regions reveals similar implications, in that institutional and social integration is imperative for furthering regional integration. Greater collaboration among regional economies, underpinned by a strong regional institutional framework, would be a priority to promote regional integration on all relevant areas. 
Table 5: World Rankings of the Overall Regional Integration Index (World average $=0.466$ )

\begin{tabular}{|c|c|c|c|c|c|c|c|c|}
\hline Rank & Economy & Score & Rank & Economy & Score & Rank & Economy & Score \\
\hline 1 & Polandc & 0.728 & 32 & Lao PDR ${ }^{b}$ & 0.495 & 63 & Mongoliab & 0.383 \\
\hline 2 & Czech Republic ${ }^{c}$ & 0.725 & 33 & Korea, Republic of ${ }^{b}$ & 0.491 & 64 & Venezuela $^{d}$ & 0.380 \\
\hline 3 & Austriac & 0.721 & 34 & New Zealand ${ }^{b}$ & 0.486 & 65 & Nepalb & 0.379 \\
\hline 4 & Portugalc & 0.703 & 35 & $\mathrm{PRC}^{\mathrm{b}}$ & 0.483 & 66 & Botswana ${ }^{a}$ & 0.376 \\
\hline 5 & Belgium ${ }^{c}$ & 0.699 & 36 & Hong Kong, China ${ }^{b}$ & 0.481 & 67 & Trinidad and Tobagod & 0.374 \\
\hline 6 & Slovak Republic ${ }^{c}$ & 0.696 & 37 & Indonesiab & 0.478 & 68 & Mexicod & 0.373 \\
\hline 7 & Germanyc & 0.693 & 38 & Paraguayd & 0.460 & 69 & Mozambique ${ }^{a}$ & 0.365 \\
\hline 8 & Finlandc & 0.686 & 39 & Japan b & 0.458 & 70 & Ecuadord & 0.362 \\
\hline 9 & Romaniac & 0.684 & 40 & Chiled & 0.433 & 71 & Bangladesh ${ }^{b}$ & 0.361 \\
\hline 10 & The Netherlands ${ }^{c}$ & 0.677 & 41 & Australiab & 0.431 & 72 & Uganda & 0.360 \\
\hline 11 & Denmarkc & 0.677 & 42 & Benin ${ }^{a}$ & 0.427 & 73 & South Africa ${ }^{a}$ & 0.351 \\
\hline 12 & Luxembourgc & 0.673 & 43 & St. Luciad & 0.426 & 74 & Jamaicad & 0.349 \\
\hline 13 & Swedenc & 0.670 & 44 & Viet Namb & 0.426 & 75 & Kenya ${ }^{a}$ & 0.348 \\
\hline 14 & Spainc & 0.669 & 45 & Zambia $^{a}$ & 0.425 & 76 & Malia & 0.345 \\
\hline 15 & Irelandc & 0.665 & 46 & Uruguayd & 0.425 & 77 & Brazild & 0.342 \\
\hline 16 & Latviac & 0.663 & 47 & Colombia $^{d}$ & 0.423 & 78 & Grenadad $^{d}$ & 0.331 \\
\hline 17 & Italyc & 0.661 & 48 & Costa Ricad & 0.422 & 79 & Pakistan ${ }^{b}$ & 0.330 \\
\hline 18 & Sloveniac & 0.655 & 49 & Togo & 0.421 & 80 & Sri Lankab & 0.330 \\
\hline 19 & France $^{c}$ & 0.650 & 50 & Argentina $^{d}$ & 0.419 & 81 & Senegala & 0.324 \\
\hline 20 & Lithuaniac $^{c}$ & 0.647 & 51 & Philippines $^{b}$ & 0.414 & 82 & Tanzania ${ }^{a}$ & 0.322 \\
\hline 21 & Hungaryc & 0.645 & 52 & Peru $^{d}$ & 0.410 & 83 & Maldives ${ }^{\mathrm{b}}$ & 0.317 \\
\hline 22 & Estoniac & 0.642 & 53 & Rwanda ${ }^{a}$ & 0.409 & 84 & Kyrgyz Republicb & 0.307 \\
\hline 23 & Bulgariac & 0.623 & 54 & Ghana $^{a}$ & 0.407 & 85 & Nigeria $^{a}$ & 0.300 \\
\hline 24 & United Kingdomc & 0.614 & 55 & Niger ${ }^{a}$ & 0.406 & 86 & Kazakhstan ${ }^{b}$ & 0.294 \\
\hline 25 & Greece & 0.590 & 56 & Malawi ${ }^{a}$ & 0.406 & 87 & Mauritius ${ }^{\mathrm{a}}$ & 0.291 \\
\hline 26 & Maltac & 0.555 & 57 & Panamad $^{d}$ & 0.405 & 88 & Georgiab $^{b}$ & 0.284 \\
\hline 27 & Cyprus ${ }^{c}$ & 0.544 & 58 & Nicaraguad $^{d}$ & 0.400 & 89 & Seychelles ${ }^{\mathrm{a}}$ & 0.265 \\
\hline 28 & Singapore ${ }^{b}$ & 0.542 & 59 & Indiab & 0.399 & 90 & Morocco ${ }^{a}$ & 0.258 \\
\hline 29 & Malaysiab & 0.536 & 60 & Cambodiab & 0.395 & 91 & Bahamas, The ${ }^{d}$ & 0.234 \\
\hline 30 & Swaziland ${ }^{a}$ & 0.507 & 61 & Namibia $^{a}$ & 0.389 & 92 & Algeriaa & 0.222 \\
\hline 31 & Thailand ${ }^{b}$ & 0.497 & 62 & Cote d'Ivoire ${ }^{a}$ & 0.389 & 93 & Sudana & 0.218 \\
\hline
\end{tabular}

Lao PDR = Lao People's Democratic Republic, PRC = People's Republic of China.

Notes: a African countries, ${ }^{b}$ Asian economies, ${ }^{c}$ EU countries, ${ }^{d}$ Latin American countries.

Source: Authors' calculations. See Table 1 for the data sources. 


\section{APPENDIXES}

\section{Appendix A: Treatment of Missing Data}

Missing data is a prevalent problem when working with many countries and indicators. Typically, some data are available only for a limited number of countries or only for certain data components. Missing data can render the composite index less reliable for countries for which limited information is available. This study is no exception, as all dimensions apart from VI include indicators with missing data. The absent data quantity is small for dimensions III and V: Cook Islands ( $V-c)$; Federated States of Micronesia (III-c, III-d); Nauru (III-c, III-d, V-c); Taipei,China (III-c, III-d, V-a, V-c), where missing data are designated in parentheses. The main problem arises with indicators for dimensions I, II, and IV. In dimensions I and II, countries with missing data are Afghanistan (II-d); Armenia (II-d); Azerbaijan (II-d); Bhutan (II-d); Brunei Darussalam (II-d); Cook Islands (I-d, I-e, II-c, II-d); Fiji (II-a, II-d); Kiribati (I-d, I-e, II-a, II-b, II-c, II-d); Marshall Islands (II-c, II-d); Federated States of Micronesia (I-a, I-b, I-c, I-d, I-e, II-a, II-d); Myanmar (II-b, II-d); Nauru (I-a, I-b, I-c, I-d, I-e, II-a, II-b, II-c, II-d); Palau (I-d, I-e, II-a, II-b, II-c, II-d); Papua New Guinea (II-d); Samoa (II-b, II-d); Solomon Islands (I-d, I-e, II-b, II-d); Tajikistan (II-d); Timor-Leste (II-a, II-b, II-d); Tonga (I-d, I-e, II-d); Turkmenistan (I-d, I-e, II-c, II-d); Tuvalu (I-d, I-e, II-a, II-b, II-c, II-d); Uzbekistan (II-c, II-d); and Vanuatu (II-a, II-b, II-d). We compute neither the corresponding dimensional index nor the overall index for these countries.

In contrast, we try to resolve the problem of missing data in dimension IV through imputation, mainly to secure a minimum number of countries for calculating APRII. Starting from indicators IV-c and IV-d, they are the Logistic Performance index (overall, LPI) and the Doing Business Index (overall, DBI) developed by the World Bank. ${ }^{14}$ These measures assess infrastructure levels from different aspects: the former examines time and costs associated with logistics processes when transporting goods across borders, while the latter primarily examines general business conditions, such as the time and costs for setting up a business, connecting utilities, registration, and so on. Yet, the two indexes are strongly related, with a correlation coefficient of $r=0.8 .{ }^{15}$ Given this strong association, we utilize a simple regression to impute missing data. Estimation results are as follows:

$$
\begin{gathered}
\mathrm{DBI}_{\mathrm{j}}=\underset{(0.32)}{3.8216+19.8326 \mathrm{LPI}_{j}}+\hat{\varepsilon}_{\mathrm{j}} \\
\mathrm{LPI}_{\mathrm{j}}=\underset{(0.00)}{0.9123+0.00)} \underset{(0.00)}{0.0322 \mathrm{DBI}_{j}}+\hat{\varepsilon}_{\mathrm{j}} \\
\mathrm{R}^{2}=0.640 \quad \mathrm{Adj}-\mathrm{R}^{2}=0.637 \quad \mathrm{~F}=229.33[0.00],
\end{gathered}
$$

where the figure in parentheses (squared brackets) is the p-value for the $t(F)$ test of statistical significance. All estimated coefficients are correctly signed and are statistically significant, with the $\mathrm{p}$ values around 0 , except the intercept in the DBI equation. Clearly, the two estimated equations are closely related, as they are regressions between two variables. $R^{2}$, adjusted $R^{2}$, and $F$ tests yield identical results across equations. The correlation coefficient equals $r=\sqrt{R^{2}}=\sqrt{0.64}=0.8$ and can also be derived from the geometric average of the two coefficient estimates, $r=\sqrt{19.8326 * 0.0322}=0.8$.

14 Overall LPI is computed by averaging six indicators with weights chosen by PCA, whereas the overall DBI is computed by arithmetically averaging 10 indicators.

15 For robustness and reliability, the correlation coefficient and the regression analysis followed are generated using 158 countries (48 Asian economies, 27 EU countries, 32 Latin American countries, 49 African countries, Canada, and the United States). 
An observation for Turkmenistan appears in LPI but not DBI. We impute this missing value for $\mathrm{DBI}$ from a prediction of the first regression, $\widehat{\mathrm{DBI}}=3.8216+19.8326 * 2.30495$, where 2.30495 is the LPI value for Turkmenistan. Nine countries have observations for DBI but not LPI: Brunei Darussalam, Kiribati, the Marshall Islands, Federated States of Micronesia, Palau, Samoa, Timor-Leste, Tonga, and Vanuatu. We compute their missing LPI values as predicted values from the second regression by substituting the respective $\mathrm{DBI}$ values into $\widehat{\mathrm{LPI}}=0.9123+0.0322 * \mathrm{DBI}$.

We calculate the indicator IV-b using United Nations Conference on Trade and Development's liner shipping bilateral connectivity index ( $L S B C I)$, which measures the integration of a country pair into global liner shipping networks. ${ }^{16} \mathrm{LSBCl}$ is unavailable for landlocked countries. Twelve Asian countries are landlocked: Afghanistan, Armenia, Azerbaijan, Bhutan, Kazakhstan, Kyrgyz Republic, Lao PDR, Mongolia, Nepal, Tajikistan, Turkmenistan, and Uzbekistan. As the indicator IV-b is to assess whether a country's shipping network is better connected regionally than globally, it may not be too restrictive to consider this ratio to be typically larger than 1 for countries having open-water access (the salient issue is by how much IV-b exceeds 1). All Asian countries with open-water access, except Georgia (0.99), exhibit IV-b exceeding $1 .^{17}$ Then, it may not be too unreasonable to surmise that shipping connectivity for landlocked countries does not differ regionally and globally. With this logic, we assume that the indicator IV-b has a value of 1 for all landlocked countries.

Finally, the indicator IV-a is based on the bilateral trade costs database of the World Bank and the United Nations Economic and Social Commission for Asia and the Pacific. This measure of trade costs (TC) is produced using the observed pattern of trade and production across countries. In principle, it can incorporate various factors that impede trade, including geographical distance, transportation costs, logistics performance, transportation network, tariffs, nontariff measures. In their regression analysis, Arvis et al. (2013) report that $\mathrm{LPI}, \mathrm{LSBCl}$, and geographical distance exert the strongest effects on TC, whereas tariffs and common features between trading partners exert relatively minor effects. We use this empirical result to impute missing values of IV-a. Specifically, we regress TC on LSBCI, LPI, and geographical distance (DISTANCE) between trading partners $j$ and $k$, thus yielding the following estimation results:

$$
\begin{aligned}
& \mathrm{TC}_{\mathrm{jk}}=\underset{(0.00)}{2.4546-10.00)} \underset{(0.00)}{1.268 \mathrm{LSCI}_{\mathrm{jk}}} \underset{(0.00)}{0.1180 \mathrm{LPI}_{\mathrm{jk}}}+\underset{(0.02)}{0.2940 \mathrm{DISTANCE}_{\mathrm{jk}}}+\hat{\varepsilon}_{\mathrm{jk}} \\
& \mathrm{R}^{2}=0.669 \quad \text { Adj }-\mathrm{R}^{2}=0.657 \quad \mathrm{~F}=53.94[0.00],{ }^{18}
\end{aligned}
$$

where $\mathrm{LPI}_{j k}$ is an average of the two countries' LPIs (i.e., $\mathrm{LPI}_{j k}=\left(\mathrm{LPI}_{j}+\mathrm{LPI}_{k}\right) / 2$ ). We obtain data for DISTANCE from the GEODIST database (Mayer and Zignago 2011). ${ }^{19}$ All coefficient estimates are signed as expected and consistent with what Arvis et al. (2013) reported: improved liner shipping connectivity and logistics performance reduce TC, while geographical distance between trading partners increases them. Based on this regression, we impute data for TC in the Marshall Islands; Solomon Islands; Taipei,China; and Turkmenistan, which are in turn used to construct IV-a.

$16 \mathrm{LSBCl}$ is derived by arithmetically averaging five indicators.

17 Georgia is contiguous to the Black Sea, which is an inner sea, and has limited access to open oceans.

18 As before, the regression analysis is undertaken using 158 countries.

19 Available at Centre d'Etudes Prospectives et d'Informations Internationales. http://www.cepii.fr 


\section{Appendix B: List of Countries in the EU, Latin America, and Africa}

\section{European Union (27):}

Austria, Belgium, Bulgaria, Cyprus, Czech Republic, Denmark, Estonia, Finland, France, Germany, Greece, Hungary, Ireland, Italy, Latvia, Lithuania, Luxembourg, Malta, The Netherlands, Poland, Portugal, Romania, Slovak Republic, Slovenia, Spain, Sweden, United Kingdom

\section{Latin America (32):}

Antigua \& Barbuda, Argentina, Bahamas, Barbados, Belize, Bolivia, Brazil, Chile, Colombia, Costa Rica, Dominica, Dominican Republic, Ecuador, El Salvador, Grenada, Guatemala, Guyana, Haiti, Honduras, Jamaica, Mexico, Nicaragua, Panama, Paraguay, Peru, St. Kitts \& Nevis, St. Lucia, St. Vincent \& the Grenadines, Suriname, Trinidad \& Tobago, Uruguay, Venezuela

\section{Africa (49):}

Algeria, Angola, Benin, Botswana, Burkina Faso, Burundi, Cameroon, Cape Verde, Central African Republic, Chad, Comoros, Congo Democratic Republic, Congo Republic, Cote d'Ivoire, Djibouti, Equatorial Guinea, Eritrea, Ethiopia, Gabon, Gambia, Ghana, Guinea, Guinea-Bissau, Kenya, Lesotho, Liberia, Madagascar, Malawi, Mali, Mauritius, Morocco, Mozambique, Namibia, Niger, Nigeria, Rwanda, Sao Tome \& Principe, Senegal, Seychelles, Sierra Leone, South Africa, Sudan, Swaziland, Tanzania, Togo, Tunisia, Uganda, Zambia, Zimbabwe. 


\section{REFERENCES}

African Union Commission, African Development Bank, and United Nations Economic Commission for Africa. 2016a. Africa Regional Integration Index Report 2016. https://www.integrateafrica.org/fileadmin/uploads/afdb/Documents/ARII-Report2016_EN_web.pdf

2016b. Methodology for Calculating the Africa Regional Integration Index (ARII). https://www.integrate-africa.org/fileadmin/uploads/afdb/Documents/ARII2016methodology_29mar16.pdf

Africa Research Bulletin: Economics, Financial and Technical Series. 2015. "African Development Bank: Regional Integration Index.” 51 (12): 20670A-20672A. doi: 10.1111/j.1467-6346.2015.06192.x.

Arvis, Jean-François, Ben Shepherd, Yann Duval, and Chorthip Utoktham. 2013. "Trade Costs and Development: A New Data Set.” World Bank. Economic Premise No. 104.

Asian Development Bank (ADB). 2016. Asian Economic Integration Report: What Drives Foreign Direct Investment in Asia and the Pacific? Manila.

—. Asia Regional Integration Center. FTA Database. https://aric.adb.org/fta (accessed January 2017).

Association of Southeast Asian Nations (ASEAN). 2015. ASEAN Economic Community Blueprint 2025. http://www.asean.org/storage/images/2015/November/aec-page/AEC-Blueprint-2025FINAL.pdf

Bourse Régionale des Valeurs Mobilières. http://www.brvm.org (accessed December 2016).

Centre d'Etudes Prospectives et d'Informations Internationales. www.cepii.fr (accessed June 2016).

Design of Trade Agreements (DESTA). www.designoftradeagreements.org (accessed June 2016).

Dreher, Axel, Noel Gaston, and Pim Martens. 2008. Measuring Globalisation: Gauging Its Consequences. Berlin: Springer Science+Business Media.

Eastern Caribbean Securities Exchange. http://www.ecseonline.com (accessed December 2016).

Gwartney, James, and Robert Lawson. 2001. Economic Freedom of the World 2001 Annual Report. Vancouver: Fraser Institute.

International Monetary Fund (IMF). Direction of Trade Statistics. www.imf.org/en/Data (accessed May 2016).

_. Coordinated Portfolio Investment Survey. http://cpis.imf.org (accessed June 2016).

_. International Financial Statistics. www.imf.org/en/Data (all accessed January 2017).

International Air Transport Association. www.iata.org (accessed July 2016).

Jackson, J. Edward. 1991. A User's Guide to Principal Components. New York: John Wiley \& Sons. doi: $10.1002 / 0471725331$. 
Johnson, Richard, and Dean Wichern. 2007. Applied Multivariate Statistical Analysis $6^{\text {th }}$ Edition. Upper Saddle River: Pearson.

Jolliffe, Ian T. 2002. Principal Component Analysis. Berlin: Springer-Verlag. doi: 10.1007/b98835.

Mayer, Thierry, and Soledad Zignago. 2011. "Notes on CEPII's Distance Measures: The GeoDist Database.” CEPII Working Paper No. 2011-25.

Naeher, Dominik. 2015. “An Empirical Estimation of Asia’s Untapped Regional Integration Potential Using Data Envelopment Analysis.” ADB Economics Working Paper Series No. 445.

Nardo, Michela, Michaela Saisana, Andrea Saltelli, and Stefano Tarantola. 2011. Tools for Composite Indicators Building. European Commission. Mauritius: Dictus Publishing.

Organisation for Economic Co-operation and Development (OECD). 2008. Handbook on Constructing Composite Indicators: Methodology and User Guide. European Commission. Paris.

South Pacific Stock Exchange. http://www.spse.com.fj (accessed December 2016).

Srivastava, Muni S. 2002. Methods of Multivariate Statistics. Toronto: Wiley-Interscience.

The Europa World Yearbook. 2016. Europa Publications.

United Nations. Commodity Trade Database. https://comtrade.un.org/ (accessed June 2016).

. Department of Economic and Social Affairs, Population Division. International Migration Stock 2015. http://www.un.org/en (accessed July 2016).

United Nations Conference on Trade and Development (UNCTAD). UNCTADstat. http://unctadstat.unctad.org/EN/ (accessed July 2016).

_. Investment Policy Hub. http://investmentpolicyhub.unctad.org (accessed June 2016).

USZE Exchange (Uzbekistan). https://www.uzse.uz (accessed December 2016).

World Bank. Doing Business 2016. http://www.doingbusiness.org (accessed June 2016).

—. Logistics Performance Index. Ipi.worldbank.org (accessed June 2016).

—. Migration and Remittances Data. http://www.worldbank.org (accessed July 2016).

World Bank and United Nations Economic and Social Commission for Asia and the Pacific. Trade Costs Database. www.databank.worldbank.org (accessed June 2016).

World Tourism Organization. 2016. Tourism Statistics Database.

World Trade Organization (WTO). 2011. World Trade Report 2011. Geneva. 


\section{Asia-Pacific Regional Integration Index: Construction, Interpretation, and Comparison}

The study develops an index to measure the degree of regional integration in Asia and the Pacific (48 economies in six subregions). The index comprises 26 indicators in six dimensions of regional integration, i.e., trade and investment, money and finance, regional value chains, infrastructure and connectivity, free movement of people, and institutional and social integration. In constructing composite indexes, principal component analysis was used to determine the weight of each dimension and indicator. The resulting indexes help assess the state of regional integration on diverse socioeconomic dimensions, evaluate progress against goals, identify strengths and weaknesses, and track progress.

\section{About the Asian Development Bank}

ADB's vision is an Asia and Pacific region free of poverty. Its mission is to help its developing member countries reduce poverty and improve the quality of life of their people. Despite the region's many successes, it remains home to a large share of the world's poor. ADB is committed to reducing poverty through inclusive economic growth, environmentally sustainable growth, and regional integration.

Based in Manila, ADB is owned by 67 members, including 48 from the region. Its main instruments for helping its developing member countries are policy dialogue, loans, equity investments, guarantees, grants, and technical assistance. 